\title{
Burkholderia phytofirmans PsJN Confers Grapevine Resistance against Botrytis cinerea via a Direct Antimicrobial Effect Combined with a Better Resource Mobilization
}

\author{
Lidiane Miotto-Vilanova ${ }^{1}$, Cédric Jacquard ${ }^{1}$, Barbara Courteaux ${ }^{1}$, Laurence Wortham ${ }^{2}$, \\ Jean Michel2 ${ }^{2}$, Christophe Clément ${ }^{1}$, Essaïd A. Barka ${ }^{1 \dagger}$ and Lisa Sanchez ${ }^{1 *}$ \\ 1 Laboratoire de Stress, Défenses et Reproduction des Plantes URVVC-EA 4707, UFR Sciences Exactes et Naturelles, \\ University of Reims-Champagne-Ardenne, Reims, France, ${ }^{2}$ Laboratoire de Recherche en Nanosciences, EA 4682, \\ Department of Physics, UFR Sciences Exactes et Naturelles, University of Reims-Champagne-Ardenne, Reims, France
}

\section{OPEN ACCESS}

Edited by:

Laure Weisskopf,

University of Applied Sciences Western Switzerland, Switzerland

Reviewed by:

Birgit Mitter,

Austrian Institute of Technology,

Austria

Gerardo Puopolo,

Fondazione Edmund Mach, Italy

*Correspondence:

Lisa Sanchez

lisa.sanchez@univ-reims.fr

tThese authors have contributed equally to this work.

Specialty section: This article was submitted to Plant Biotic Interactions, a section of the journal Frontiers in Plant Science

Received: 27 May 2016 Accepted: 04 August 2016 Published: 23 August 2016

Citation:

Miotto-Vilanova L, Jacquard $C$, Courteaux B, Wortham L, Michel J, Clément C, Barka EA and Sanchez L (2016) Burkholderia phytofirmans PsJN Confers Grapevine Resistance against Botrytis cinerea via a Direct Antimicrobial Effect Combined with a Better Resource Mobilization. Front. Plant Sci. 7:1236. doi: 10.3389/fpls.2016.01236
Plant innate immunity serves as a surveillance system by providing the first line of powerful weapons to fight against pathogen attacks. Beneficial microorganisms and Microbial-Associated Molecular Patterns might act as signals to trigger this immunity. Burkholderia phytofirmans PsJN, a highly efficient plant beneficial endophytic bacterium, promotes growth in a wide variety of plants including grapevine. Further, the bacterium induces plant resistance against abiotic and biotic stresses. However, no study has deciphered triggered-mechanisms during the tripartite interaction between grapevine, B. phytofirmans PsJN and Botrytis cinerea. Herein, we showed that in contrast with classical rhizobacteria, which are restricted in the root system and act through ISR, $B$. phytofirmans PsJN is able to migrate until aerial part and forms at leaves surface a biofilm around $B$. cinerea mycelium to restrict the pathogen. Nevertheless, considering the endophytic level of PSJN in leaves, the plant protection efficacy of $B$. phytofirmans PsJN could not be explained solely by its direct antifungal effect. Deeper investigations showed a callose deposition, $\mathrm{H}_{2} \mathrm{O}_{2}$ production and primed expression of $P R 1, P R 2$, $P R 5$, and JAZ only in bacterized-plantlets after pathogen challenge. The presence of PSJN modulated changes in leaf carbohydrate metabolism including gene expression, sugar levels, and chlorophyll fluorescence imaging after Botrytis challenge. Our findings indicated that protection induced by B. phytofirmans PSJN was multifaceted and relied on a direct antifungal effect, priming of defense mechanisms as well as the mobilization of carbon sources in grapevine leaf tissues.

Keywords: antibiosis, B. phytofirmans PsJN, B. cinerea, grapevine, induced-resistance, priming

\section{INTRODUCTION}

Plants have to face a broad range of invading pathogens. In response, they can deploy a large set of defense responses including constitutive pre-existing physical and chemical barriers as well as an innate immunity activated after pathogen perception (Zipfel, 2008; Boller and Felix, 2009). The first line of recognition is based on the detection via pattern recognition receptors (PRRs) 
of evolutionarily conserved elicitors, also called microbe-, pathogen-, or damage-associated molecular patterns (MAMPs; PAMPs; DAMPs) (Dangl and Jones, 2001; Jones and Dangl, 2006). MAMP-triggered immunity (MTI) is characterized by early and long-term physiological responses including reactive oxygen species (ROS), ethylene (ET) production, MAPK activation, reprogramming of transcriptome and metabolome (e.g., production of phytoalexins and SA), and callose deposition (Boller and Felix, 2009). One of the earliest responses at the time of pathogen assault is the production of ROS, which plays a crucial role to restrain pathogen development through programmed cell death at the site of infection (Torres et al., 2006; Mur et al., 2008). The second stage of perception corresponds to the direct or indirect recognition of pathogen effectors by intracellular immune receptors leading to effector-triggered immunity (ETI; Jones and Dangl, 2006). MTI and ETI will answer to activate early signaling events in plant defense (Tsuda and Katagiri, 2010). Plant hormones, salicylic acid (SA), jasmonic acid (JA), ET, and abscisic acid (ABA) appear as key regulators in defense-signaling networks (Pieterse et al., 2009).

Pathogen attack not only affects plant defenses reactions but can also lead to changes in photosynthesis rates and consequently carbohydrates metabolism. Indeed, during the resistance response, the production of defense-related compounds becomes the high priority of the plant leading to reduced photosynthetic rates until the end of the pathogen growth (Rojas et al., 2014). As plant defense responses may alter the pool size of a range of metabolic intermediates, photosynthetic metabolism likely will be influenced as it will be regulated to meet the cell/plant requests. The photosynthesis decreases through the infection process as a result of leaf metabolism perturbation attributed to sugar-mediated repression of photosynthetic gene expression (Bonfig et al., 2006). Cell wall invertase (Cw-Inv) catalyzes the cleavage of the sucrose into glucose and fructose, and supply sink organs with carbohydrates, playing thus a crucial role in the regulation of carbohydrate partitioning (Roitsch et al., 2003; Roitsch and Gonzalez, 2004; Tauzin and Giardina, 2014). Additionally, starch reserves may also be converted to soluble sugars (Chou et al., 2000) that may act as signals to induce pathogenesis-related (PR) protein genes and to increase plant resistance (Solfanelli et al., 2006).

The use of plant growth-promoting rhizobacteria (PGPR) to induce plant resistance is one of the alternatives developed to protect crops against damages caused by various forms of stress (Yang et al., 2009). Induced resistance in grapevine against Botrytis cinerea, the gray mold agent, by beneficial rhizobacteria has been reported (Aït Barka et al., 2002; Verhagen et al., 2010, 2011; Gruau et al., 2015). Among the plant-growth promoting bacteria, Burkholderia phytofirmans strain PsJN is able to colonize a variety of genetically unrelated plants such as potato and tomato (Conn et al., 1997; Nowak et al., 1998), maize, switchgrass (Kim et al., 2012), both endophytically and at the rhizoplane. In addition to colonize grapevine tissues (Compant et al., 2005), B. phytofirmans PsJN promotes the growth of roots and also of the aerial part after root inoculation (Ait Barka et al., 2000). In addition, during the interaction between B. phytofirmans PsJN and grapevine, the bacterium triggers a transient extracellular alkalinization, the production of SA and accumulation of defense-related transcripts, suggesting that this PGPR is perceived by grapevine cells potentially via MAMP detection (Bordiec et al., 2011). Moreover, Trda et al. (2014) showed that flagellin from B. phytofirmans PsJN induced resistance against $B$. cinerea and suggest its implication to evade from plant's immune recognition system. The endophytic presence of $B$. phytofirmans PsJN leads to protection against abiotic stresses including cold in grapevine (Fernandez et al., 2012a; Theocharis et al., 2012), drought in wheat (Naveed et al., 2014) or salt and freezing in Arabidopsis (Pinedo et al., 2015; Su et al., 2015). It has also been shown that this strain reduces damages caused by chilling in grapevine through a priming of plant defense responses and changes in primary metabolism, particularly an increase of soluble sugars concentration and an accumulation of proline (Ait Barka et al., 2006; Fernandez et al., 2012a,b; Theocharis et al., 2012). In addition, the bacterium improves tolerance against biotic stress as Verticillium sp. in tomato (Sharma and Nowak, 1998) or B. cinerea in grapevine (Ait Barka et al., 2000; Aït Barka et al., 2002). However, the mechanisms involved beyond the observed induced resistance are not elucidated.

To decipher the mechanisms induced by B. phytofirmans PsJN to confer grapevine resistance against $B$. cinerea, we determined (i) the direct antimicrobial effect of PsJN on $B$. cinerea growth; (ii) the effect of $B$. phytofirmans PsJN on the early signaling events (callose, ROS), and on the induction of defense response signaling pathway (gene expression); and finally (iii) changes in leaf carbohydrate metabolism including gene expression, sugar levels and chlorophyll fluorescence imaging after Botrytis challenge.

\section{MATERIALS AND METHODS}

\section{Plant Material}

Plantlets of Vitis vinifera cv. Chardonnay (clone 7535) were micro-propagated by nodal explants grown on $15 \mathrm{ml}$ of agar medium in $25 \mathrm{~mm}$-culture tubes as described by Ait Barka et al. (2006). Cultures were performed in a growth chamber under white fluorescent light $\left(200 \mu \mathrm{mol} / \mathrm{m}^{2} \mathrm{~s}\right)$, with $16 \mathrm{~h} / 8 \mathrm{~h}$ day/night photoperiod at a constant temperature of $26^{\circ} \mathrm{C}$.

\section{Microorganisms}

Burkholderia phytofirmans strain PsJN tagged with GFP was cultivated in King's B liquid medium supplemented with kanamycin $(50 \mu \mathrm{g} / \mathrm{ml})$ for $24 \mathrm{~h}$ with agitation of $180 \mathrm{rpm}$ at $28^{\circ} \mathrm{C}$. Bacteria were collected after centrifugation at $4500 \mathrm{~g}$ at $4^{\circ} \mathrm{C}$ for $15 \mathrm{~min}$ and suspended in phosphate-buffer saline (PBS $10 \mathrm{mM}, \mathrm{pH}$ 6.5). The concentration of bacteria was determined by spectrophotometry $(600 \mathrm{~nm})$ and adjusted to $10^{9} \mathrm{CFU} / \mathrm{ml}$ with $\operatorname{PBS}\left(D_{0}=0.8\right)$.

Escherichia coli was cultivated in LB liquid medium for $24 \mathrm{~h}$ with agitation of $180 \mathrm{rpm}$ at $37^{\circ} \mathrm{C}$. The concentration of bacteria was determined by spectrophotometry $(600 \mathrm{~nm})$ and adjusted to $10^{9} \mathrm{CFU} / \mathrm{ml}$ with PBS $\left(D_{0}=1\right)$.

Botrytis cinerea strain 630 was grown on solid medium tomato juice $[33 \%(\mathrm{v} / \mathrm{v})$, agar $5 \%(\mathrm{w} / \mathrm{v})]$ at $20^{\circ} \mathrm{C}$. For the inoculum 
preparation, conidia of $B$. cinerea were collected from 20-day-old culture plates by scratching the Petri dishes surface with sterile potato dextrose broth (PDB $12 \mathrm{~g} / \mathrm{l}$ ) and filtered to remove hyphae. Conidial concentrations were measured and the final density was adjusted to $10^{5}$ conidia/ml. After incubation during $3 \mathrm{~h}$ at $20^{\circ} \mathrm{C}$ and $150 \mathrm{rpm}$, germinated spores were used for plant inoculation.

\section{Inoculation of In vitro-Plantlets with B. phytofirmans Strain PsJN and Infection by $B$. cinerea}

Roots of 4-week-old grapevine plantlets were inoculated with $200 \mu \mathrm{l}$ of bacterial (E. coli or PsJN) inoculum $\left(10^{9} \mathrm{CFU} / \mathrm{ml}\right)$. Control and bacterized plantlets were then grown for an additional week before their transfer aseptically into sterile Magenta boxes containing $60 \mathrm{~g}$ of soil. After 3 days, each leaf of the plantlet was covered by 2 drops ( $5 \mu \mathrm{l}$ each) of suspension of $B$. cinerea germinated spores. This protocol was used for measures of necrosis diameter.

For $\mathrm{H}_{2} \mathrm{O}_{2}$ production, callose deposition, analysis of gene expression, sugar/starch measures, and IMAGING-PAM analysis, plantlets were sprayed with the germinated spore suspension of $B$. cinerea in order to have a homogenous application. Plantlets were placed in growth chamber at $20^{\circ} \mathrm{C}$. Leaves were then sampled at different time points after $B$. cinerea challenge.

\section{Observation of B. cinerea Mycelium Development after Trypan Blue and Aniline Blue Staining}

Leaves of control and root-bacterized plantlets collected 24, 48, 72 hpi with $B$. cinerea were stained with lactophenol-trypan blue and destaining in saturated chloral hydrate as described in Koch and Slusarenko (1990) or with $0.05 \%$ aniline blue. The mycelium development was then observed using 3D (Keyence, France) or epifluorescence microscope.

\section{Rhizoplane and Endophytic Colonization}

To determine rhizoplane colonization of B. phytofirmans PsJN in the roots, the samples were removed from soil and vortexed (240 rpm) with PBS for approximately $1 \mathrm{~min}$. The homogenate was serially diluted in 10 fold steps and cultured on King's B medium plates (in triplicates) supplemented with kanamycin (50 $\mathrm{\mu g} / \mathrm{ml}$ ). For endophytic colonization, roots were surface sterilized with $70 \%$ ethanol for $3 \mathrm{~min}$, followed by $0.01 \%$ commercial bleach and a $0.01 \%$ Tween 20 solution for $1 \mathrm{~min}$, and then washed four times in distilled water ( 1 min each time). Leaves were surface sterilized with $0.01 \%$ commercial bleach and a $0.01 \%$ Tween 20 solution for $3 \mathrm{~min}$, and then washed four times in distilled water ( $1 \mathrm{~min}$ each time). The samples were then ground with $1 \mathrm{ml}$ of PBS. The homogenate was serially diluted in 10 fold steps and cultured on King's B medium plates (triplicates) supplemented with kanamycin $(50 \mu \mathrm{g} / \mathrm{ml})$. The bacterial colonies were counted after 3 days of incubation at $28^{\circ} \mathrm{C}$.

\section{Spore Germination Assay}

$B$. cinerea spore germination with $10^{2}, 10^{4}$, or $10^{6} \mathrm{CFU} / \mathrm{ml}$ of B. phytofirmans PsJN was assessed in 96-well microplates. $B$. cinerea were collected in Potato Dextroxe Broth (PDB) and were added in each well to a final concentration of 5,000 spores, in triplicate, in a total volume of $100 \mu \mathrm{l}$. The plates were incubated at $20^{\circ} \mathrm{C}$ in the dark. Germ tube growth was observed $24 \mathrm{~h}$ after challenge using inverted light microscopy (Leica, Wetzlar, Germany).

To test the effect of different soluble sugars (sucrose, glucose, fructose) on $B$. cinerea spore germination, conidia were collected in PDB supplemented with different sugar concentrations $(0.1,1$, or $2 \%)$. Germ tubes were observed by inverted light microscopy (Leica, Wetzlar, Germany) 24h later. Both experiments were repeated twice (each in triplicates).

\section{Direct Effect of Burkholderia phytofirmans PsJN on B. cinerea Growth}

The 4-week-old grapevine leaves of plantlets were sprayed with different concentration of $B$. phytofirmans PsJN $\left(0,10^{2}, 10^{3}, 10^{4}\right.$, and $10^{6} \mathrm{CFU} / \mathrm{ml}$ ) and after $30 \mathrm{~min}$ infected with $2 \mathrm{ml}$ of $B$. cinerea $\left(10^{5}\right.$ conidia $\left./ \mathrm{ml}\right)$. Plantlets were placed in the growth chamber at $20^{\circ} \mathrm{C}$. Leaves sampled $0,2,24,48$, and $72 \mathrm{~h}$ after challenge were immediately frozen in liquid nitrogen and stored at $-80^{\circ} \mathrm{C}$. Frozen samples were used for RNA extraction and BcActin gene analysis. The means \pm standard deviations originated from two independent experiments realized in duplicates, each replicate consisted of a pool of six plantlets.

\section{Detection of $\mathrm{H}_{2} \mathrm{O}_{2}$}

For histochemical detection of $\mathrm{H}_{2} \mathrm{O}_{2}$, the 3,3-benzidine- $\mathrm{HCl}$ (DAB, Sigma-Aldrich) method was used according to ThordalChristensen et al. (1997). Fresh entire leaves from control and bacterized plantlets were immersed in the DAB solution $\left(1 \mathrm{mg} / \mathrm{ml}\right.$ for $6 \mathrm{~h}$ at $37^{\circ} \mathrm{C}$ ), at $8 \mathrm{~h}$ post infection with $B$. cinerea, before observations under an optical microscope. The $\mathrm{H}_{2} \mathrm{O}_{2}$ content was also evaluated according to Theocharis et al. (2012), with some modifications. Briefly, leaf powder (100 mg) was homogenized in $200 \mu \mathrm{l}$ of ice-cold acetone and the mixture was centrifuged at $13,500 \times g$ for $10 \mathrm{~min}$. Cold water $(100 \mu \mathrm{l})$ and $40 \mu \mathrm{l}$ of $5 \%$ titanyl sulfate were added to the supernatant, followed by $200 \mu \mathrm{l}$ of $1 \mathrm{~N} \mathrm{NH}_{4} \mathrm{OH}$ solution to precipitate the peroxidetitanium complex. After centrifugation at $6,000 \times g$ for $5 \mathrm{~min}$, the supernatant was discarded and the pellet was washed with cold acetone. The precipitate was then dissolved in $600 \mu \mathrm{l}$ of $2 \mathrm{~N} \mathrm{H}_{2} \mathrm{SO}_{4}$ and the final volume adjusted to $800 \mu \mathrm{l}$ with cold water. The absorbance of the solution was read at $415 \mathrm{~nm}$, and $\mathrm{H}_{2} \mathrm{O}_{2}$ content was calculated according to a standard curve. The means \pm standard deviations originated from three independent experiments realized in duplicates, each replicate consisted of a pool of six plantlets.

\section{Callose Deposition}

Callose deposition was observed as described in Schenk et al. (2014). Detached leaves were collected at $24 \mathrm{~h}$ post infection with 
B. cinerea and then incubated overnight in $95 \%$ ethanol. Destained leaves were washed in $150 \mathrm{mM} \mathrm{K}_{2} \mathrm{POH}_{4}$ for $30 \mathrm{~min}$ and thereafter stained for $2 \mathrm{~h}$ with $0.01 \%$ aniline blue in $150 \mathrm{mM}$ $\mathrm{K}_{2} \mathrm{POH}_{4}$. Micrographs were taken by epifluorescence microscope with UV filter (BP, 340-380; LP, $425 \mathrm{~nm}$ ). This experiment was repeated twice and each replicate consisted of six leaves.

\section{RNA Extraction and Real-Time Quantitative RT-PCR}

For each sample, $50 \mathrm{mg}$ of leaves were ground in liquid nitrogen. Total RNA was isolated using Extract'All (Eurobio) and $250 \mathrm{ng}$ was used for reverse-transcription using the Absolute MAX 2-Step QRT-PCR SYBR ${ }^{\circledR}$ Green Kit (Thermo Electron) ${ }^{\text {TM }}$ according to the manufacturer's instructions. The transcript levels were determined by real-time quantitative PCR using the Chromo4 system (BIO-RAD, Hercules, CA, USA) and the SYBR Green Master Mix PCR kit as recommended by the manufacturer (Applied Biosystems). PCR reactions were carried out in duplicates in 96-well plates (15 $\mu$ l per well) in a buffer containing $1 \mathrm{x}$ SYBR Green I mix (including Taq polymerase, dNTPs, SYBR Green dye), $280 \mathrm{nM}$ forward and reverse primers and 1:10 dilution of reverse transcript RNA. After denaturation at $95^{\circ} \mathrm{C}$ for $15 \mathrm{~min}$, amplification occurred in a two-step procedure: $15 \mathrm{~s}$ of denaturation at $95^{\circ} \mathrm{C}$ and $1 \mathrm{~min}$ of annealing/extension at $60^{\circ} \mathrm{C}$, with a total of 30 cycles. Identical thermal cycling conditions were used for all targets. Specific primers were designed using the Primer Express software (Applied Biosystems, Foster City, CA, USA) and are presented in the Supplementary Table S1. PCR efficiency of the primer sets was calculated by performing real-time PCR on serial dilutions. For each experiment, PCR reactions were performed in duplicate and 3 independent experiments were analyzed. Results correspond to means \pm standard deviation (SD) of duplicate reactions of three independent experiments. Relative gene expression

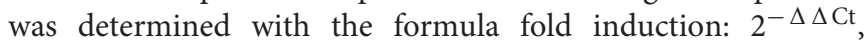
where $\Delta \Delta C \mathrm{t}=(C \mathrm{t}$ GI [unknown sample]-Ct GI [reference sample])-(Ct reference genes [unknown sample]-Ct reference genes [reference sample]). GI is the gene of interest. EF1a and $60 R S P$ are used as internal controls. The reference sample is the "control+buffer" sample, chosen to represent $1 \mathrm{x}$ expression of the gene of interest. The means \pm standard deviations originated from three independent experiments realized in duplicates, each replicate consisted of a pool of six plantlets.

\section{Transmission Electron Microscopy of Grapevine Leaf Cell Structure}

Fresh leaves were collected at $24 \mathrm{~h}$ post infection with B. cinerea and fixed for $20 \mathrm{~h}$ at room temperature in $1 \%(\mathrm{w} / \mathrm{v})$ glutaraldehyde in $0.1 \mathrm{M}$ phosphate buffer ( $\mathrm{pH} 7.2$ ) with $0.5 \%$ $(\mathrm{w} / \mathrm{v})$ sucrose and $0.2 \%(\mathrm{v} / \mathrm{v})$ Tween 20 . After three rinses $(5 \mathrm{~min}$ each) with the phosphate buffer containing $0.3 \%(\mathrm{w} / \mathrm{v})$ sucrose, samples were fixed for $4 \mathrm{~h}$ in $1 \%(\mathrm{w} / \mathrm{v})$ osmium tetroxide in phosphate buffer with $0.5 \%(\mathrm{w} / \mathrm{v})$ sucrose. The samples were then dehydrated in an alcohol series, transferred to acetone, and finally, they were embedded in Araldite. Transverse ultrathin sections (80 nm nominal thickness) were cut (Reichert Jung
Ultracut E) from the Araldite-embedded block and mounted on 200 mesh copper grids. Sections were observed under a JEM2100F TEM (JEOL) without post-staining. Micrographs were recorded using an Orius 200D CCD camera (Gatan). For this experiment, 5 leaves from five plants were used.

\section{Sucrose, Glucose, and Fructose Analysis}

Fifty $\mathrm{mg}$ of frozen leaves powder was mixed with $500 \mu \mathrm{l}$ of $0.1 \mathrm{M}$ potassium phosphate buffer $(\mathrm{pH} 7.5)$ and centrifuged at $1000 \mathrm{~g}$ at $4^{\circ} \mathrm{C}$ for $15 \mathrm{~min}$. The supernatants were recuperated and an aliquot $(50 \mu \mathrm{l})$ was used to measure the concentration of sucrose, glucose, and fructose. The analysis was performed using enzymatic kits (Megazyme) according to manufacturer's protocol. The means \pm standard deviations originated from two independent experiments realized in duplicates, each replicate consisted of a pool of six plantlets. Results were expressed in $\mathrm{mg} / \mathrm{g}$ dry weight.

\section{Starch Extraction and Analysis}

For starch analysis, the pellets from soluble sugar extraction were re-suspended and vortexed in dimethyl sulfoxide-8 $\mathrm{M}$ hydrochloric acid (4/1/ v/v). Starch was dissolved over $30 \mathrm{~min}$ at $60^{\circ} \mathrm{C}$ with constant agitation. After centrifugation for $5 \mathrm{~min}$ at $5000 \mathrm{~g}, 100 \mu \mathrm{l}$ supernatant were added with $100 \mu \mathrm{l}$ iodineHCL solution $\left(0.06 \% \mathrm{KI}\right.$ and $0.003 \% \mathrm{I}_{2}$ in $\left.0.05 \mathrm{M} \mathrm{HCL}\right)$ and $1 \mathrm{ml}$ distilled water and incubated at room temperature for $15 \mathrm{~min}$. The spectrophotometer was zeroed with the control (blank), and absorbance was read at $600 \mathrm{~nm}$. The means \pm standard deviations originated from three independent experiments realized in duplicates, each replicate consisted of a pool of six plantlets. The results were expressed in $\mathrm{mg} / \mathrm{g}$ dry weight.

\section{IMAGING-PAM Analysis}

Chlorophyll fluorescence parameters and the redox change of P700 were measured with an IMAGING-PAM measuring system (Heinz Walz, Germany) using the saturation pulse method. Control and bacterized plantlets were dark adapted for $30 \mathrm{~min}$ to determine the minimal level of fluorescence $\left(F_{0}\right)$ and the maximal fluorescence $\left(F_{\mathrm{m}}\right)$ after a saturating flash $\left(1 \mathrm{~s} ; 13,000 \mu \mathrm{mol} / \mathrm{m}^{2} \mathrm{~s}\right)$. Leaves were then exposed to an actinic illumination of $79 \mu \mathrm{mol} / \mathrm{m}^{2}$ s. After fluorescence stabilization, a second saturating flash was imposed to determine the maximal fluorescence $\left(F_{\mathrm{m}}{ }^{\prime}\right)$ of light-adapted inflorescences. Removal of the actinic light and exposure to a short period of far-red light allowed measurement of the zero level of fluorescence $\left(F_{0}{ }^{\prime}\right)$. The electron transport rate of PS II is calculated according to the equation $[$ ETR $=\mathrm{Y}(\mathrm{II}) \times \mathrm{PAR} \times$ $0.5 \times$ PAR absorptivity]. The effective PSII quantum yield, Y(II), is calculated according to the equation of Genty et al. (1989). The quantum yield of regulated energy dissipation in PSII, Y(NPQ), and the quantum yield of non-regulated energy dissipation in PSII, Y(NO), is calculated according to Kramer et al. (2004). Note that $\mathrm{Y}(\mathrm{II})+\mathrm{Y}(\mathrm{NPQ})+\mathrm{Y}(\mathrm{NO})=1$. The data were collected out of necrosis area. The means \pm standard deviations originated from three independent experiments realized in duplicates, each replicate consisted of six plantlets. 


\section{Statistical Analysis}

Statistical analyses were carried out using the statistical software SISVAR. Shapiro-Wilk test $(\alpha>0.05)$ was used for normality test, and Levene's test $(\alpha>0.05)$ for homogeneity of variances test. The data of gene expression, sugars/starch, $\mathrm{H}_{2} \mathrm{O}_{2}$, Imaging PAM was analyzed using two-way analysis of variance (ANOVA). When differences in the means were significant, Tukey test ( $\alpha=0.05)$ was applied to determine which treatments were significantly different from others. For lesion diameter Student's $t$-tests $(\alpha>0.05)$ was used to compare lesion area between inoculated and non-inoculated plants.

\section{RESULTS}

\section{Burkholderia phytofirmans PsJN-Triggered Immunity in Grapevine against $B$. cinerea}

In order to test the capacity of B. phytofirmans PsJN to protect grapevine in our system, we performed infection on leaves with $B$. cinerea strain 630 on control or root-bacterized plantlets. Assays performed on detached leaves from bacterized plantlets inoculated with drops of $B$. cinerea strain 630 conidia showed that B. phytofirmans significantly reduced Botrytis-related necrosis by approximately 50\% 72 hpi (Figure 1A). In addition, whole potted-plant infection was carried out to quantify the gray mold disease symptoms in control versus bacterized plants. Therefore, whole plants were sprayed with $B$. cinerea spores suspension and development of decay was monitored 24, 48, 72, and $96 \mathrm{hpi}$. As for detached leaves, disease symptoms were significantly reduced in bacterized plants, confirming the protective impact of B. phytofirmans against $B$. cinerea (Figure 1B). Further, fungal growth was monitored in planta at 2, 8, 24, 48, and $72 \mathrm{hpi}$ by analyzing the transcript levels of the $B$. cinerea actin gene (BcActin) by qRT-PCR. While no significant differences were observed between control and PsJN root-inoculated plants at 2, 8, and 24 hpi (Supplementary Figure S1A), the Bc-Actin transcript level in bacterized plantlets was approximately 250fold and 800-fold lower compared to non-bacterized plantlets at 48 and $72 \mathrm{hpi}$, respectively. In order to monitor that the induced resistance of plantlets toward $B$. cinerea was not due to a general effect of bacterization, we carried out the same $B$. cinerea infection procedure using E. coli-bacterized plantlets. Results showed that no protection was conferred by the presence of $E$. coli against the fungus (Supplementary Figure S1A,B). These data clearly indicated that the significantly enhanced resistance toward Botrytis infection is related to the presence of B. phytofirmans PsJN.

In addition, $B$. cinerea development was also visualized in planta by microscopy (3D and epifluorescence) after trypan (Supplementary Figure S1C) or aniline blue (Supplementary Figures S1D) staining. As shown in Supplementary Figure S1, the development of the fungus was moderately reduced in bacterized plantlets at 24 hpi compared to non-bacterized ones. However, fungal hyphae growth was clearly inhibited in bacterized plantlets 72 hpi with B. cinerea. Interestingly, while PsJN was not observed
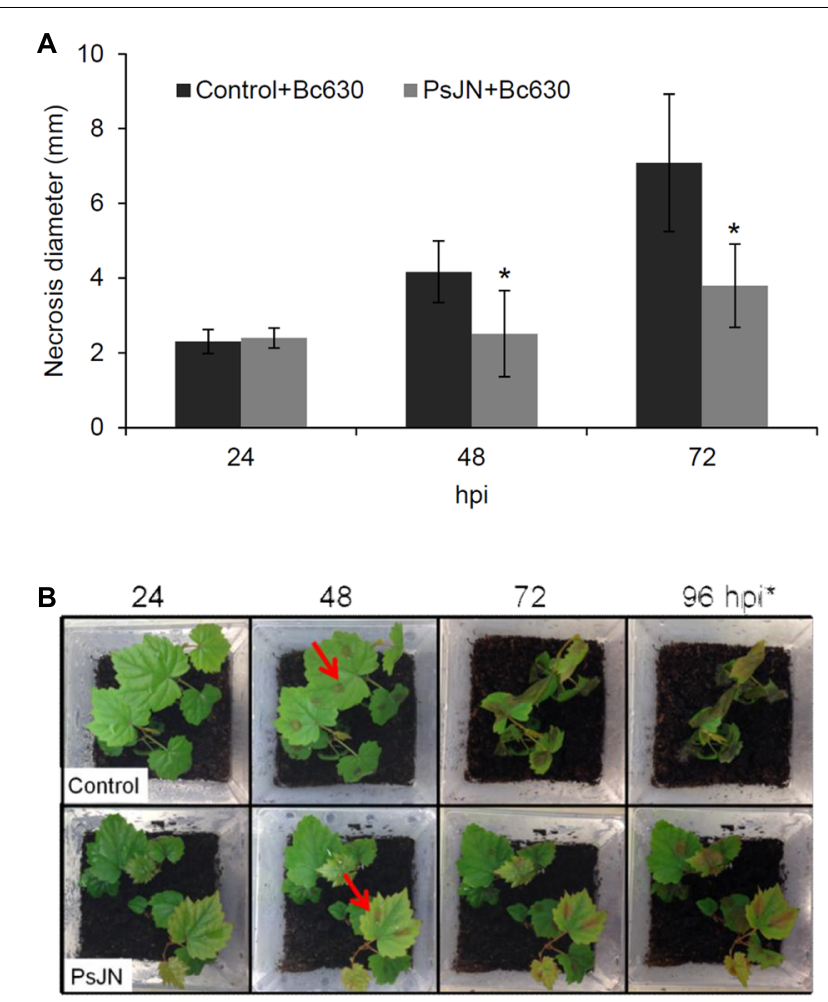

FIGURE 1 | Burkolderia phytofirmans PsJN protects grapevine against Botrytis cinerea. (A) Lesion diameter in detached leaves of plantlets inoculated or not with B. phytofirmans 48 and $72 \mathrm{~h}$ after infection with B. cinerea. * indicates significant differences $(P \leq 0.05)$ as determined by Tukey test analysis. (B) Grapevine vitroplants inoculated or not with B. phytofirmans PsJN (cv. Chardonnay) 24, 48, 72, and 96 hpi with $B$. cinerea. Arrows indicate drops of $B$. cinerea suspension.

at the leaves surface in the absence of the pathogen, the bacteria were detected at the surface, surrounding the fungal mycelium in botrytized leaves (Figure 2).

\section{Implication of the Burkholderia phytofirmans PsJN-Direct Antifungal Effect on Grapevine Protection}

To test if the bacterium could act via an antimicrobial effect, we estimated its effect on fungal spore germination and also the ability of $B$. cinerea to develop in the host tissues when inoculated rapidly after direct leaves bacterization.

For spore germination assay, the conidial concentration was adjusted to $5.10^{4}$ conidia/ml and incubated during $3 \mathrm{~h}$ at $150 \mathrm{rpm}$. B. phytofirmans PsJN was then added at $0,10^{2}, 10^{4}$, or $10^{6}$ $\mathrm{CFU} / \mathrm{ml}$ and B. cinerea germ tubes growth was observed $24 \mathrm{~h}$ after. Germ tubes growth assay showed an inhibition of $32 \%$, $62 \%$, and $88 \% 20 \mathrm{~h}$ after addition of $10^{2}, 10^{4}$, and $10^{6} \mathrm{CFU} / \mathrm{ml}$ of bacteria, respectively (Figure 3A).

To establish the role of the direct antifungal effect of B. phytofirmans PsJN in the inability of $B$. cinerea to grow in planta, leaves of 6-week-old plantlets were sprayed with B. phytofirmans PsJN at different concentrations and then 

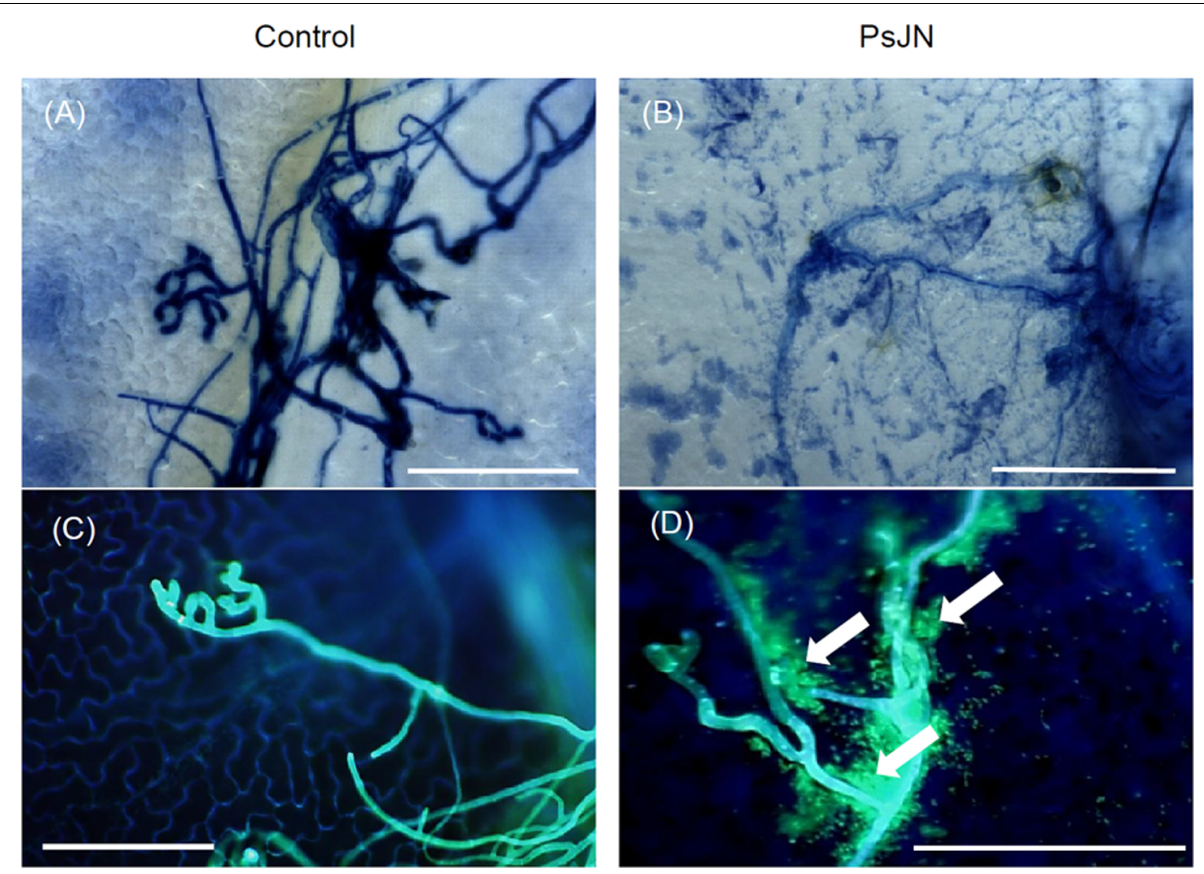

FIGURE 2 | Interaction between B. phytofirmans and B. cinerea in planta. Microscopic observations of infected grapevine leaves root-inoculated or not with B. phytofirmans PsJN at 72 hpi with B. cinerea, stained with trypan blue (A,B) and $0.05 \%$ aniline blue (C,D). Observations were realized with a microscope 3D and an epifluorescence microscope, respectively. Representative pictures of three independent experiments are shown. Arrows indicate B. phytofirmans tagged GFP. Bars $=100 \mu \mathrm{m}$.

infected by Botrytis $\left(10^{5}\right.$ conidia/ml) 30 min later to prevent the full establishment of plant defense responses. The quantification of BcActin in leaves, as an indicator of the rate of fungal growth in planta, was then realized 2, 24, 48, and 72 hpi with $B$. cinerea. Our results showed a net dose dependent impact of $B$. phytofirmans PsJN on fungal development (Figure 3B). Indeed, no significant difference with control was observed at $10^{2} \mathrm{CFU} / \mathrm{ml}$. However, at highest concentrations $\left(10^{4}\right.$ and $\left.10^{6} \mathrm{CFU} / \mathrm{ml}\right)$, a very low level of BcActin gene expression was detected, indicating a strong protective effect of $B$. phytofirmans PsJN at these concentrations.

\section{Burkholderia phytofirmans PsJN Primes $\mathrm{H}_{2} \mathrm{O}_{2}$ Production and Callose Deposition after Pathogen Challenge}

$\mathrm{H}_{2} \mathrm{O}_{2}$ production is an important part of grapevine defense system (Boubakri et al., 2012) and is considered as a signal molecule to activate disease resistance (Pastor et al., 2013). No significant $\mathrm{H}_{2} \mathrm{O}_{2}$ production was observed in response to bacterium or fungus inoculation (Figure 4A). However, when bacterized plantlets were inoculated with Botrytis, the $\mathrm{H}_{2} \mathrm{O}_{2}$ production was primed. In addition, the $\mathrm{H}_{2} \mathrm{O}_{2}$ generation was localized in situ after DAB (3,3-diaminobenzidine) staining. In control and bacterized plants without the pathogen, no $\mathrm{H}_{2} \mathrm{O}_{2}$ generation was visualized except in veins (Figures $4 \mathbf{B}, \mathrm{C}$ ), which may probably correspond to the lignification process. In botrytized plantlets, quite staining spots were sporadically observed on leaves (Figure 4B) corresponding most likely to the Botrytis conidia-generated ROS (Figure 4C). On the opposite,
DAB deposits observed in bacterized plantlets following Botrytis infection were due to $\mathrm{H}_{2} \mathrm{O}_{2}$ production by plant cells and cover the whole leave surface, indicating that B. phytofirmans PsJN primed an oxidative burst in grapevine leaves after challenge by the fungus.

Callose depositions are an important characteristic of defense mechanisms and are thought to reinforce the cell wall at fungal penetration sites to impede infections (Underwood, 2012; Malinovsky et al., 2014). Therefore, the impact of B. phytofirmans PsJN on callose synthesis in grapevine plantlets was monitored after aniline blue staining at 24 hpi (Figure 4D). The results indicate the absence of callose deposition in the control plant. A similar result was observed after botrytis challenge. In contrast, an obvious callose deposition was observed in stomata of B. phytofirmans PsJN-inoculated plantlets. The observed callose accumulation has been strengthened after infection by Botrytis. These data indicated that the presence of B. phytofirmans PsJN in grapevine plantlets primed callose deposition after pathogen challenge.

\section{Priming of Both SA- and JA-Related Genes by the PGPR}

To further elucidate possible mechanisms contributing to B. phytofirmans PsJN-IR against B. cinerea, the expression of SA- (PR1, PR2, PR5, and VvWRKY transcription factor 3), JA(HPLA, JAZ, and AOC1) (Gauthier et al., 2014) ET (ETR1) and ABA-related genes ( $V v Z E P, V v N C E D)$ (Hayes et al., 2010) was monitored in control and root-bacterized plantlets, $24 \mathrm{~h}$ after 


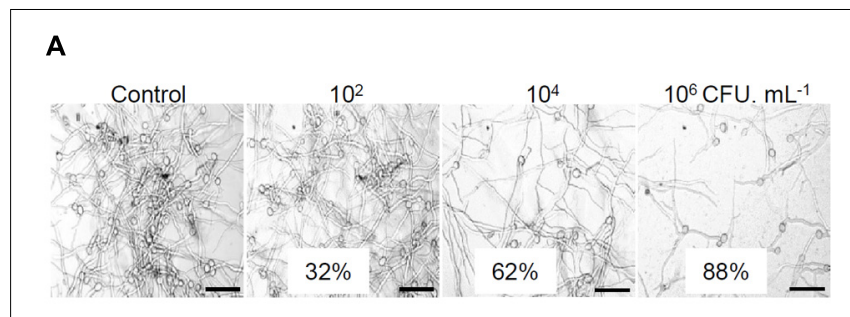

B



FIGURE 3 | Direct effect of B. phytofirmans PsJN on Botrytis. (A) Effect of $B$. phytofirmans PsJN on B. cinerea spore germination. Conidia were placed in growth medium supplemented with different concentrations $\left(10^{2}\right.$, $10^{4}, 10^{6} \mathrm{CFU} / \mathrm{ml}$ ) of B. phytofirmans PsJN. Germ tubes were observed by inverted light microscopy $24 \mathrm{~h}$ later. Bars $=50 \mu \mathrm{m}$. (B) Protection due to antifungal effect. Expression analysis of $B$. cinerea actin by real time PCR in leaves sprayed directly with the bacterium at different concentrations $\left(10^{2}\right.$, $10^{3}, 10^{4}$, and $10^{6} \mathrm{CFU} / \mathrm{mll} 30 \mathrm{~min}$ before Botrytis infection.

challenge by $B$. cinerea. In bacterized plantlets, no significant difference was observed in transcript accumulation except a slight repression of $V v Z E P$ and a slight induction of AOC (Figure 5). These results indicated that bacteria, alone, modulate slightly the gene transcript levels. The Botrytis infection alone induced a significant increase in PR5, WRKY, AOC, HPLA, and JAZ gene expression levels. In response to Botrytis, the bacterized plantlets exhibited a stronger expression of $P R$ genes ( $P R 1, P R 2$, and $P R 5)$, and JAZ. Taken together, these data suggest that, in response to a subsequent infection by $B$. cinerea, B. phytofirmans PsJN potentiates the simultaneous induction of the SA- and JA- related genes.

\section{Burkholderia phytofirmans PsJN Alleviates Photosystem Irreversible Damages}

The activation of plant defenses requires an increased energy supply that ultimately must come from photosynthesis (Bolton, 2009; Shoresh et al., 2010). In order to evaluate the effect of root-inoculation with $B$. phytofirmans PsJN on photosynthesis before and 24,48 , and $72 \mathrm{~h}$ post-infection with $B$. cinerea, changes in excitation flux at PSII were monitored. Photosynthetic parameters including effective PSII quantum yield Y(II), quantum yield of non-regulated energy dissipation $\mathrm{Y}(\mathrm{NO})$, quantum yield of regulated energy dissipation $\mathrm{Y}(\mathrm{NPQ})$, relative photosynthetic electron transport [ETR] and maximum PSII quantum yield $\left(F_{\mathrm{v}} / F_{\mathrm{m}}\right)$ were evaluated (Figure 6). The false color scales shown at the bottom of the fluorescence images indicate the amplitude of the particular parameter (Figure 6A). Before infection with the pathogen, no significant difference between bacterized and non-bacterized plantlets was observed regarding the monitored photosynthetic parameters. However, $24 \mathrm{~h}$ after inoculation with $B$. cinerea, bacterized plantlets exhibit faint symptoms (Figure 6A) and a significant increase of $\mathrm{Y}$ (II) in comparison to control (Figure 6B). In addition, ETR was significantly improved in bacterized plantlets $48 \mathrm{~h}$ after pathogen challenge (Figure 6D). Further, the efficiency of PSII quantum yield Y(II) decreased in control plantlets $48 \mathrm{~h}$ after infection with $B$. cinerea in parallel to a significant increase of $\mathrm{Y}(\mathrm{NPQ})$. These changes were accompanied by a significant decrease in both $F_{\mathrm{v}} / F_{\mathrm{m}}$ and ETR (Figures 6C,D). At 72 hpi, Y(II) value was lower in non-bacterized plantlets compared to bacterized ones probably due to the significant increase of quantum yield of non-regulated energy dissipation $\mathrm{Y}(\mathrm{NO})$. The latter parameter indicates an irreversible damage of photosynthetic apparatus as confirmed by the decreased $F_{\mathrm{V}} / F_{\mathrm{m}}$ ratio (Figure 6C). Interestingly, photosynthetic parameters were not affected by $B$. cinerea infection in bacterized plantlets.

\section{Modifications of Soluble Sugar and Starch Contents}

Sugars are the final products of photosynthesis and have been reported to be involved as a signal in plant defense mechanisms (Rojas et al., 2014). Herein, gene expression of $\alpha$ and $\beta$-amylase, a CwINV, a sucrose synthase (SUSY), three hexoses (HT1, HT3, HT5), one putative polyol/monosaccharide transporters (PMT5), and two hexokinases (HXK1, HXK3) were analyzed. Analysis of gene expression showed that $\beta$-amylase expression was slightlty repressed while expression of PMT5 was induced by $B$. cinerea (Figure 7 ). The expression of the remaining genes was not affected. When lonely inoculated, $B$. phytofirmans PsJN repressed the expression of $\beta$-amylase while PMT5 was induced. When bacterized-plantlets were infected with $B$. cinerea infection, the expression of $\beta$-amylase was significantly repressed. Moreover, significant increases were found at transcriptional levels for $\alpha$-amylase, CwINV and HT5 upon challenge with $B$. cinerea compared to non-bacterized ones.

Sucrose, glucose, and fructose contents in leaves were measured at $0,24,48$, and 72 hpi in bacterized and nonbacterized plantlets upon challenge with $B$. cinerea. While sucrose, glucose, and fructose remain constant during kinetics in non-bacterized plantlets, a moderate decrease in sucrose content was observed at $72 \mathrm{~h}$ in bacterized plantlets, supporting that B. phytofirmans PsJN might consume this sugar (Figure 8). In the same time, glucose content increased at $48 \mathrm{~h}$ whereas no significant fluctuation was occurred for fructose. In response to $B$. cinerea, the non-bacterized plantlets exhibit a constant 

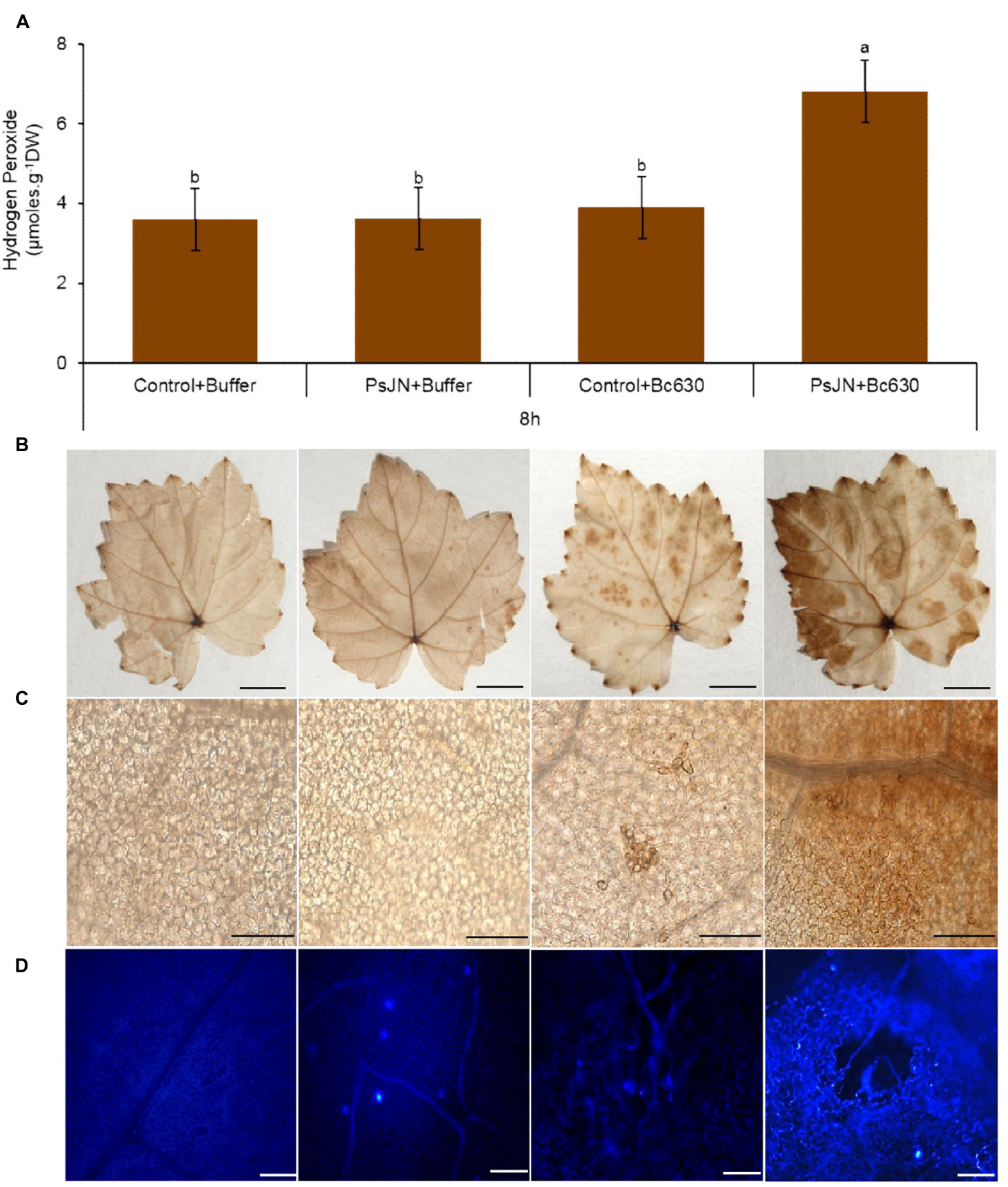

FIGURE 4 | Accumulation of hydrogen peroxide $\left(\mathrm{H}_{2} \mathrm{O}_{2}\right)$ and callose in control and bacterized (PsJN) grapevine plantlets after infection with B. cinerea. (A) Dosage of $\mathrm{H}_{2} \mathrm{O}_{2}$ in non-bacterized and bacterized grapevine plantlets at 8 hpi. Data presented are the means $\pm \mathrm{SD}$ from three independent experiments. Different letters above each bar indicate significant differences $(P \leq 0.05)$ as determined by Tukey's analysis. (B) $\mathrm{H}_{2} \mathrm{O}_{2}$ accumulation visualized by $\mathrm{DAB}$ in grapevine leaves at $8 \mathrm{hpi}$. Detached leaves were stained with DAB 0,01\% solution. Bars = $5 \mathrm{~mm}$. (C) Microscopic observations of the DAB-stained leaves shows in (A). Bars $=100 \mu \mathrm{m}$. (D) Callose deposition in response to B. cinerea in leaves of control and bacterized plantlets. Chlorophylls were removed with ethanol to eliminate the auto-fluorescence background in callose visualization with the organic fluorophore aniline blue. Micrographs were taken by fluorescence microscopy using a $405 \mathrm{~nm}$ diode laser for aniline blue excitation. Distribution and amount of callose depositions in leaves stained with aniline blue at $24 \mathrm{~h}$ after pathogen challenge. Bars $=100 \mu \mathrm{m}$.

decrease in sucrose content during the infection process in parallel with an increase in glucose and fructose contents but with a more pronounced effect for the latter (Figure 8). When bacterized plantlets were infected with the fungus, sucrose content increased transiently at $24 \mathrm{hpi}$, then decreased during the infection process. In meanwhile, the level of glucose increased 


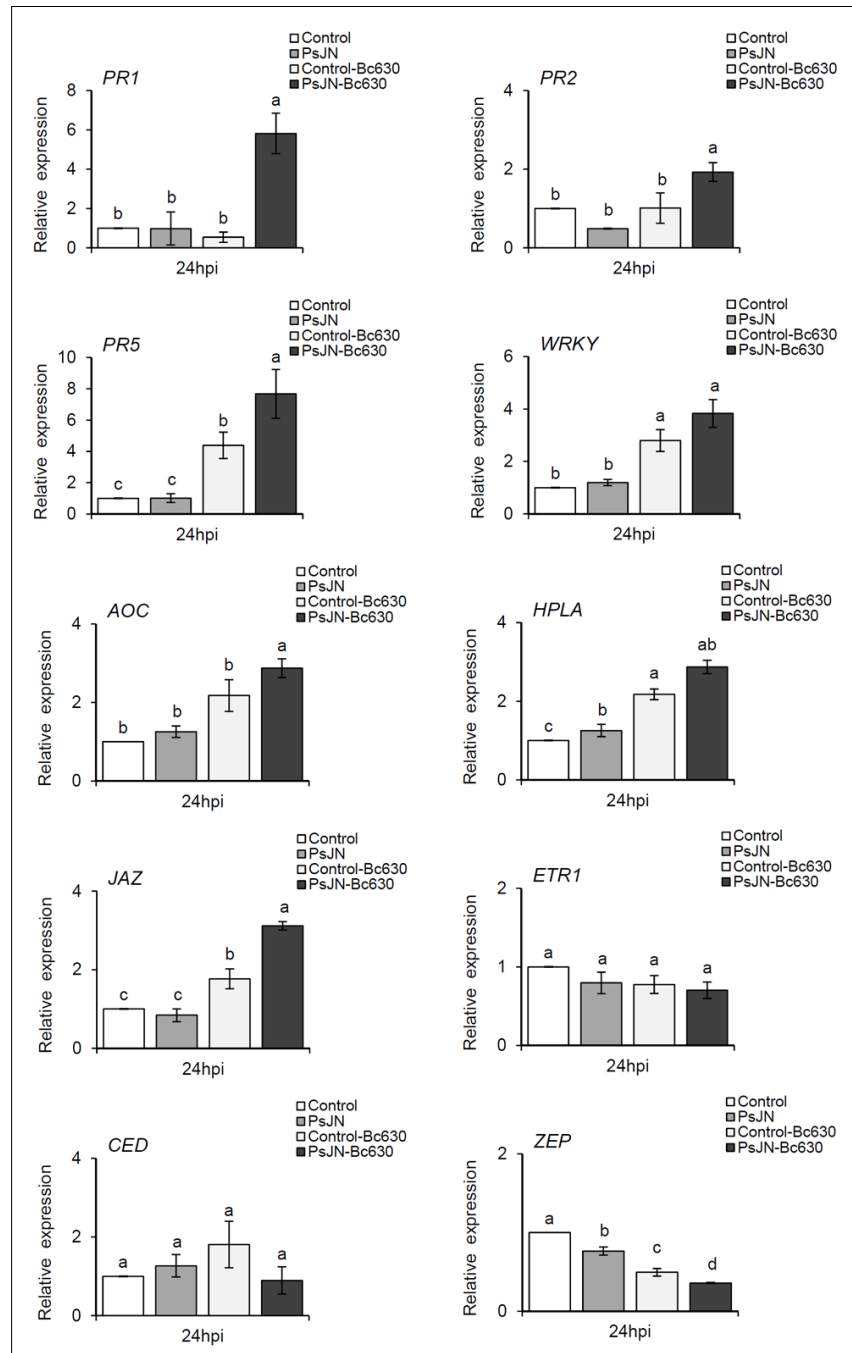

FIGURE 5 | Defense related-gene expression in grapevine leaves inoculated or not with $B$. phytofirmans PsJN after pathogen challenge. Transcript accumulation of PR1, PR2, PR5, WKKY, AOC, HPLA, JAZ, ETR1, ZEP, and CED genes was determined by qRT-PCR 24 hpi with $B$. cinerea. Gene transcript levels were normalized using two reference genes ( $E F 1 \alpha, 60$ $R S P$ ) as internal controls. Results are expressed as the fold increase in transcript level compared to control leaves treated with buffer. Values shown are means $\pm \mathrm{SD}$ of three independent repetitions (each repetition was realized in triplicates). Letters a-d indicate significant differences $(P \leq 0.05)$ between treatments as determined by Tuckey analysis.

to reach the maximum level at 48 hpi then slightly decreased. Nevertheless, no significant change was observed for fructose content (Figure 8).

Since starch constitutes the main carbohydrate reserve of plants, the starch content was monitored in leaves after B. cinerea challenge in bacterized and non-bacterized plantlets (Figure 9A). Twenty-four hours after $B$. cinerea infection, the starch content was enhanced in leaves of bacterized-plantlets, while a decrease was observed in response to Botrytis. Interestingly, after pathogen challenge, starch level was primed in bacterized-plantlets. These results were confirmed by TEM observations (Figure 9B).

\section{DISCUSSION}

\section{B. phytofirmans PsJN Reduced B. cinerea Growth Development}

During the interaction between grapevine plants and B. phytofirmans PsJN, the bacterium is able to colonize and diffuse inside plant tissues through xylem vessels ending at stomata chamber of leaves (Compant et al., 2005). This study provided new insights in deciphering the mechanisms of B. phytofirmans PsJN-IR against $B$. cinerea in grapevine by reporting for the first time that following root inoculation, B. phytofirmans PsJN is able to colonize the entire plant before exiting through the leaf stomata, and then forms a biofilm, at leaves surface, around mycelium of $B$. cinerea. This result indicates that the bacterium behaves firstly as endophyte, then as an epiphyte since it goes out to the leave surface to fight against the invader, suggesting the attractive chemotaxis of B. phytofirmans PsJN by the pathogen, which leads to an antibiosis effect of the bacterium. As far we know, this is the first time that such behavior was reported in vivo for a PGPR. Related to antibiosis impact, our results showed that $B$. cinerea development was inhibited dependently on B. phytofirmans PsJN concentrations. But, considering the endophytic level of PsJN in leaves tissues (Supplementary Figure S2), we might assume that the observed $B$. phytofirmans PsJN protection against $B$. cinerea could not be explained solely by its direct antifungal effect.

\section{B. phytofirmans PsJN Potentiated Grapevine Defense Mechanisms}

Microorganisms, for instance rhizobacteria, have been found to prime defense reactions against $B$. cinerea (Verhagen et al., 2010, 2011). The $\mathrm{H}_{2} \mathrm{O}_{2}$ production, considered as a signal molecule for activating disease resistance (Pastor et al., 2013), is an important part of grapevine defense system (Boubakri et al., 2012). After pathogen challenge, we observed an early $\mathrm{H}_{2} \mathrm{O}_{2}$ accumulation (8 hpi) only in bacterized plantlets, indicating a priming effect of the bacterium. These data are in agreement with the faster accumulation of ROS in potato plantlets inoculated with B. phytofirmans PsJN after Phytophthora infection reported by Hubalek (2009). This early ROS production may explain partly the observed restriction of Botrytis in bacterized plantlets since Huang et al. (2011) have reported the direct toxic effects of ROS on pathogens.

Several studies underlined the importance of stress-induced callose synthesis in defense mechanisms (Ellinger and Voigt, 2014). Herein, a callose deposition was observed in stomatal guard cells of bacterized plantlets confirming earlier reports indicating that callose deposition is triggered by classical bacterial MAMPs, flg22 (Luna et al., 2011), EF-Tu (Lu et al., 2009), LPS (Sun et al., 2012), and peptidoglycans hairpins (Ellinger and Voigt, 2014). Moreover, the callose deposition was primed in PsJN-bacterized plants suggesting the involvement of callose deposition in grapevine disease resistance toward $B$. cinerea, as reported previously against downy mildew (Trouvelot et al., 2008). 


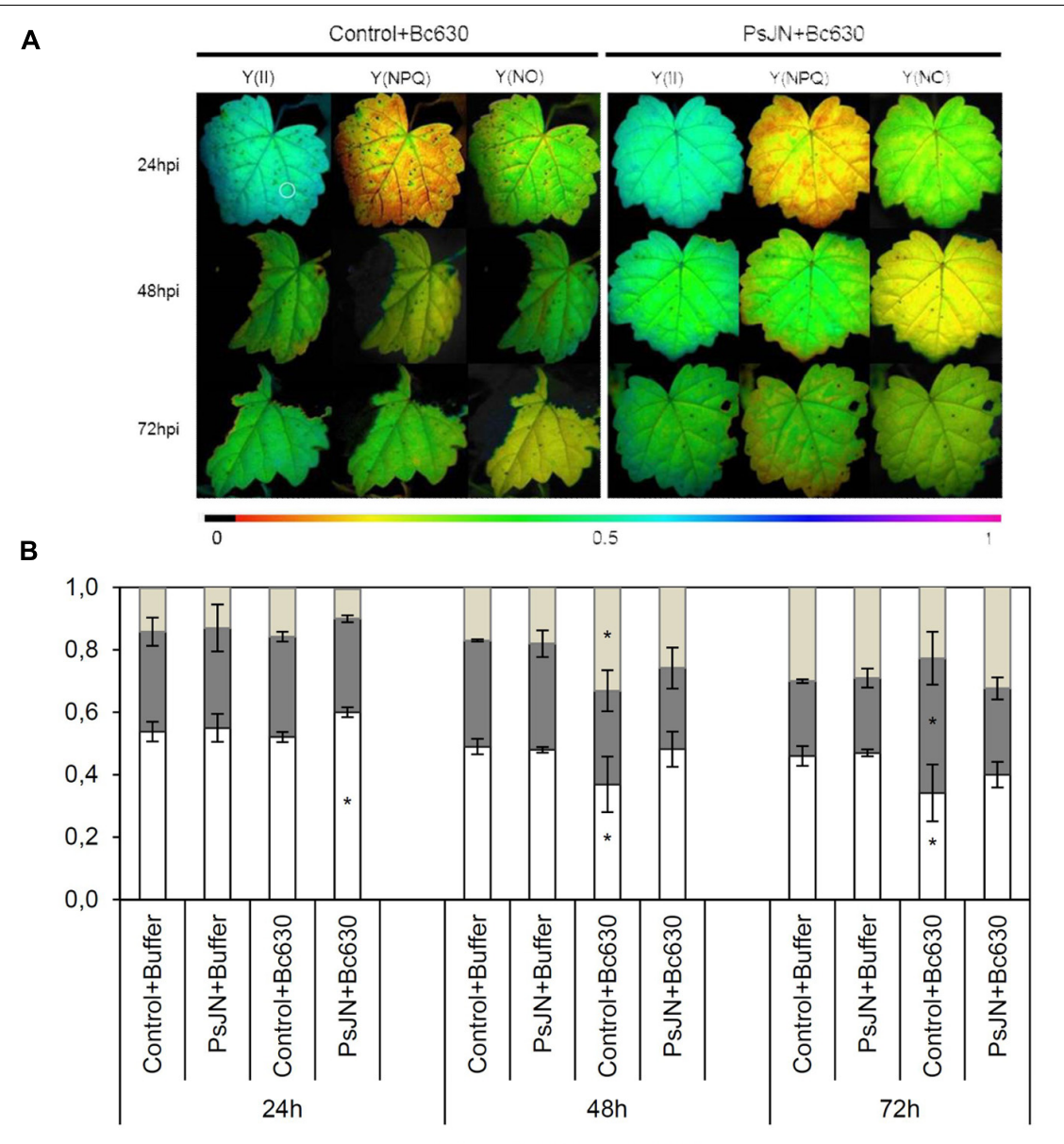

$\square Y(I I) \quad \square Y(N O) \quad \square Y(N P Q)$


FIGURE 6 | Fluorescence parameters from grapevine leaves inoculated or not with B. phytofirmans PsJN 24, 48, and 72 hpi with B. cinerea.

(A) Images of the effective PSII quantum yield Y(II), the quantum yield of regulated energy dissipation Y(NPQ) and of non-regulated energy dissipation $Y(N O)$. The pixel value display is based on a false-color scale ranging from black $(0.000)$ via red, yellow, green, blue, to purple (ending at 1.00). The figure shows representative images of one from three independent experiments. (B) Changes in excitation flux at PSII in infected leaves of plantlets root-inoculated or not with B. phytofirmans PsJN 24, 48, and 72 hpi with B. cinerea. Data presented in (B) are the means \pm SD from three independent experiments and asterisks above each bar indicate significant differences $(P \leq 0.05)$ as determined by Tuckey analysis. (C) Maximum PSIl quantum yield $\left(F_{\mathrm{v}} / F_{\mathrm{m}}\right)$ and $(\mathbf{D})$ relative photosynthetic electron transport [ETR]. Results represented the means \pm SD from three independent experiments.

Our data demonstrated that B. phytofirmans PsJNinduced resistance against Botrytis is mediated by enhanced expression of defense genes solely after pathogen inoculation.
These results are in accordance with the previous study on abiotic stress, which showed that PsJN acts as a priming agent for defense responses in grapevine plantlets against 

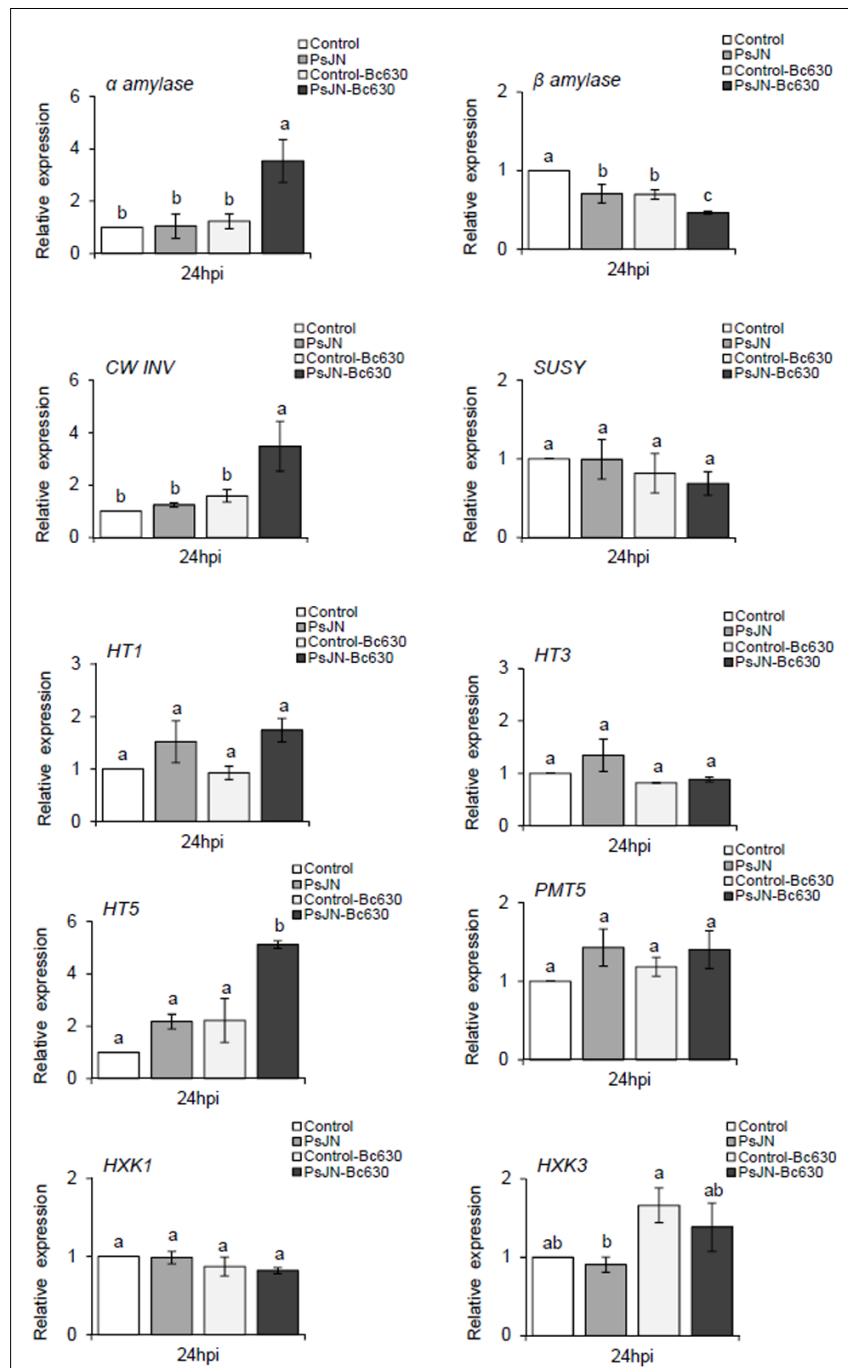

FIGURE 7 | Sugar related-gene expression in grapevine leaves inoculated or not with $B$. phytofirmans PsJN after pathogen challenge. Transcript accumulation of $\alpha$-amylase, $\beta$-amylase, CWINV, SUSY, HT1, HT3, HT5, PMT5, HXK1, and HXK3 genes was determined by qRT-PCR $24 \mathrm{hpi}$ with $B$. cinerea. Gene transcript levels were normalized using two reference genes $(E F 1 \alpha, 60 R S P)$ as internal controls. Results are expressed as the fold increase in transcript level compared to control leaves treated with buffer. Values shown are means \pm SD of three independent repetitions (each repetition was realized in triplicates). Letters $a-b$ indicate significant differences $(P \leq 0.05)$ between treatments as determined by Tuckey analysis.

low temperatures $\left(4^{\circ} \mathrm{C}\right)$ rather than wastefully activating defenses (Theocharis et al., 2012). If SA signaling sector is generally associated with immunity to biotrophs while JA and ET are important for immunity to necrotrophs (Glazebrook, 2005), there are plenty of exceptions to this rule (Ferrari et al., 2003; Sanchez et al., 2012). In this way, herein a concomitant enhancement of expression of both SA- (PR1, PR2, PR5, and WRKY) and JArelated genes (AOC and $J A Z$ ) has been observed in B. phytofirmans PsJN-bacterized plants after the challenge by $B$. cinerea.
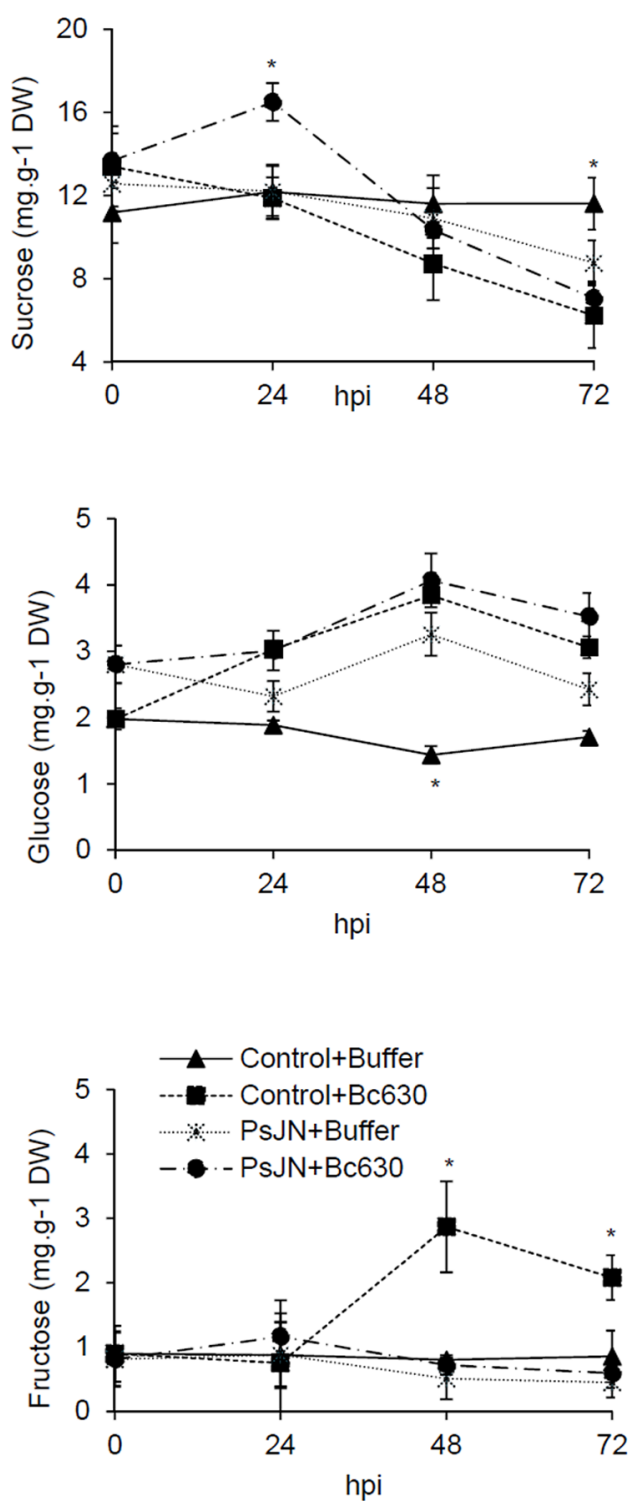

FIGURE 8 | Sucrose, glucose, and fructose concentrations in control and bacterized grapevine leaves 24,48 , and $72 \mathrm{~h}$ post infection with B. cinerea. Data presented are the means \pm SD of duplicates from two independent experiments. * above each bar indicate significant differences $(P \leq 0.05)$ as determined by Tuckey analysis.

\section{B. phytofirmans PsJn Modulated the Carbohydrates Metabolism}

During their co-evolution, plants and pathogens participate in a metamorphic tug-of-war, in which the plant limits pathogen access to nutrients and initiates immune responses, while pathogen develops adaptive approaches to redirect for their own nutrient flux and suppress plant immunity (Chen et al., 2010). The induced source-to-sink transition is not without consequences for photosynthesis and primary metabolism. In this way, several reports have postulated a relationship between sugar regulations, the expression of defense genes, 


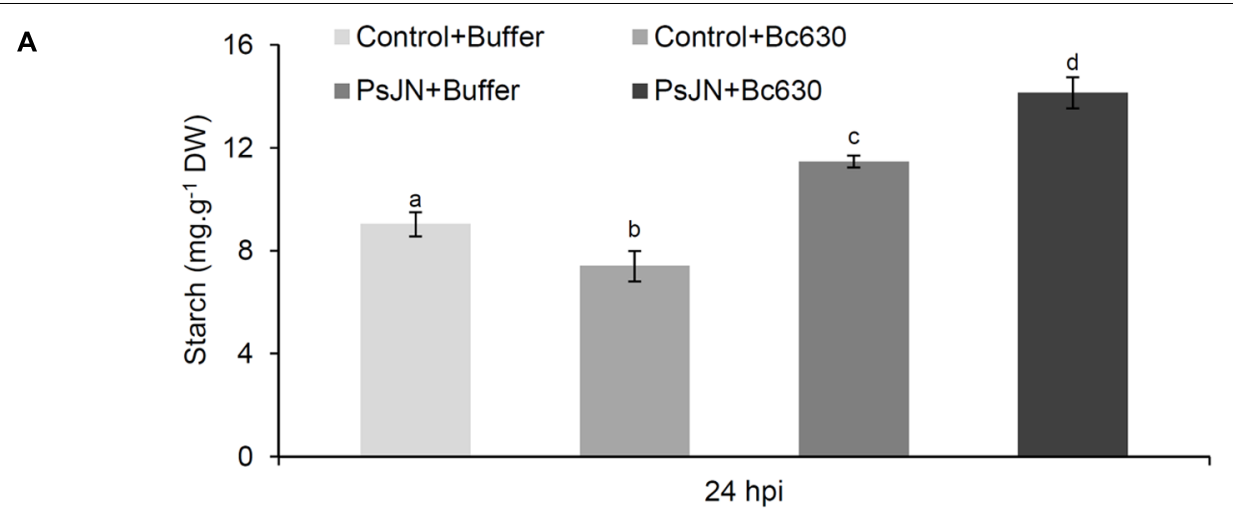

B

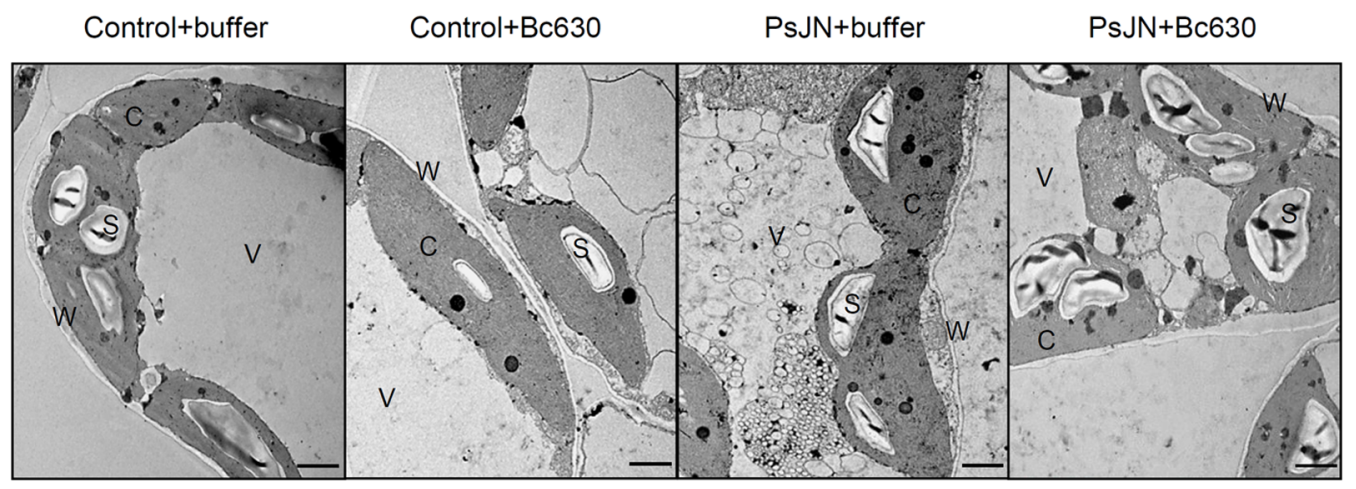

FIGURE 9 | Starch analysis in control and bacterized grapevine leaves after challenging with $\boldsymbol{B}$. cinerea. (A) Data presented are the means \pm SD of duplicates from three independent experiments. Different letters above each bar indicate significant differences $(P \leq 0.05)$ as determined by Tukey analysis.

(B) Transmission electron micrographs of leaves ultrastructure inoculated or not with B. phytofirmans PsJN (cv. Chardonnay) 24 h post infection with B. cinerea. C cytoplasm, S starch, $V$ vacuole, and W cell wall.

and the activation of systemic resistance (Herbers et al., 1996). Twenty hours post-infection, when the symptoms of B. cinerea infection did not appear yet, an increase of Y(II) was observed in bacterized plantlets, suggesting the protective role of bacteria on grapevine photosynthetic apparatus during the first step of infection. A significant decrease of effective quantum yield of PSII (Y(II)) accompanied by a quantum yield of regulated energy dissipation [Y(NPQ)] increase were observed in non-bacterized plantlets $48 \mathrm{~h}$ after inoculation with $B$. cinerea. These changes could result in lower efficiency of PSII photochemistry and increased heat dissipation (Horton and Ruban, 2005). At $72 \mathrm{hpi}$, the increase in $\mathrm{Y}(\mathrm{NO})$ and the decline of $F_{\mathrm{v}} / F_{\mathrm{m}}$ induced by $B$. cinerea in non-bacterized plantlets indicated that the regulation mechanisms of nonphotochemical dissipation of energy were blocked, making grapevine-plantlets unable to protect themselves against damage from excessed illumination. This oscillation was accompanied by a decrease in the electron transport flux, indicating that probably, B. cinerea damaged irreversibly the PSII and photosynthetic electron transport chain. In line with our results, several reports on photosynthesis and plant defense have indicated that photosynthesis rates are altered after infection with several plant pathogens (Bonfig et al., 2006; Berger et al., 2007). Our data indicated also that B. phytofirmans PsJN is able to prevent these irreversible damages probably by restricting mycelial development.

As indicated above, the decrease in photosynthetic metabolism, in parallel with an enhanced cellular demands during the resistance response, initiate the transition from source status to sink status in infected tissues. This transition is often accompanied by intensified gene expression and activity of invertases (Roitsch et al., 2003; Roitsch and Gonzalez, 2004). CwINV regulates phloem unloading in some sink organs (Roitsch et al., 2003) and produces hexose substrates that may be acquired by hexose transporters (HTs) (Hayes et al., 2007). In this context, our results exhibit that in response to $B$. cinerea, the upregulation of CwINV and HT5 was stronger in PsJN-bacterized plantlets compared to control ones, indicating a priming effect of the bacterium. Identical coordinated up-regulation of these two genes (CwINV and HT5) was previously described in grapevine leaves in response to both biotic (powdery and downy mildew) and abiotic (wound) stresses (Hayes et al., 2010). These changes may reflect the higher demand for assimilates for defense reactions and the withdrawal of assimilates by the pathogen (Berger et al., 2007). A significant increase of sucrose content was observed only in bacterized-plantlets after pathogen 
challenge, which may be linked to the better photosynthetic capacity observed with B. phytofirmans PsJN. Indeed, sucrose is of central importance as a product of photosynthesis but also the form in which most carbohydrates are transported between cells and throughout the plant. Sucrose hydrolysis is catalyzed by invertases and the consequence is the shifts of the apoplastic sucrose/hexose ratio in favor of hexoses. A constant decrease of sucrose level was observed $24 \mathrm{hpi}$, whereas a slight increase of glucose level with a constant level of fructose were observed in PsJN-bacterized plantlets. It is well known that leafassociated microbes use plant resources such as carbohydrates, amino acids and organic acids (Trouvelot et al., 2014). Our results indicated that B. phytofirmans PsJN is able to use glucose and fructose, as described previously by (Sessitsch et al., 2005). A clear accumulation of fructose was observed at 48 and $72 \mathrm{hpi}$ in control plantlets infected by the fungus. The capacity of fungi to use soluble sugars to germinate is strain dependent (Doehlemann et al., 2005). In this study, the effect of different concentrations of sucrose, glucose , and fructose on spore germination showed the inability of Botrytis strain 630 to use fructose (Supplementary Figure S3). After pathogen challenge, B. phytofirmans PsJN was able to induce HT5, which is the only HT able to bind fructose (Vignault et al., 2005; Hayes et al., 2007). Interestingly, these data suggest that $B$. phytofirmans PsJN redirects carbohydrates in favor to fructose, that is not useful for $B$. cinerea.

Gene expression analysis revealed a down-regulation of $\beta$-amylase and an up-regulation of $\alpha$-amylase in response to $B$. cinerea in bacterized plantlets. A similar pattern was reported in grapevine leaves infected by Plasmopara viticola (Gamm et al., 2011). The latters argued that $\alpha$-amylase replaces $\beta$-amylase for starch degradation in Plasmopara-infected leaves. Starch is the main carbon reserve in plants and may be converted to soluble

\section{REFERENCES}

Ait Barka, E., Belarbi, A., Hachet, C., Nowak, J., and Audran, J. C. (2000). Enhancement of in vitro growth and resistance to gray mould of Vitis vinifera co-cultured with plant-promoting rhizobacteria. FEMS Microbiol. Lett. 186, 91-95. doi: 10.1111/j.1574-6968.2000.tb09087.x

Aït Barka, E., Gognies, S., Nowak, J., Audran, J.-C., and Belarbi, A. (2002). Inhibitory effect of endophyte bacteria on Botrytis cinerea and its influence to promote the grapevine growth. Biol. Control 24, 135-142. doi: 10.1016/S10499644(02)00034-8

Ait Barka, E., Nowak, J., and Clément, C. (2006). Enhancement of chilling resistance of inoculated grapevine plantlets with a plant growth-promoting rhizobacterium, Burkholderia phytofirmans strain PsJN. Appl. Environ. Microbiol. 72, 7246-7252. doi: 10.1128/aem. 01047-06

Berger, S., Sinha, A. K., and Roitsch, T. (2007). Plant physiology meets phytopathology: plant primary metabolism and plant-pathogen interactions. J. Exp. Bot. 58, 4019-4026. doi: 10.1093/jxb/erm298

Boller, T., and Felix, G. (2009). A renaissance of elicitors: perception of microbe-associated molecular patterns and danger signals by pattern-recognition receptors. Annu. Rev. Plant Biol. 60, 379-406. doi: 10.1146/annurev.arplant.57.032905.105346

Bolton, M. D. (2009). Primary metabolism and plant defense-fuel for the fire. Mol. Plant Microbe Interact. 22, 487-497. doi: 10.1094/MPMI-22-5-0487

Bonfig, K. B., Schreiber, U., Gabler, A., Roitsch, T., and Berger, S. (2006). Infection with virulent and avirulent $P$. syringae strains differentially affects sugars. In our study, a significant increase of starch content was observed in B. phytofirmans PsJN-bacterized plantlets compared to control ones, confirming previous results obtained during grapevine-B. phytofirmans interaction (Ait Barka et al., 2006). Herein, we showed for the first time a priming effect of B. phytofirmans PsJN on starch accumulation after Botrytis challenge, indicating that PsJN may help plants to respond more effectively and more rapidly to fungal attack by a better sugar mobilization.

\section{AUTHOR CONTRIBUTIONS}

LM-V, CJ, EB, and LS designed the research. LM-V, CJ, BC, LW, JM, EB, and LS carried out the experiments and analysis/interpretation of data. LM-V, CJ, CC, EB, and LS wrote the manuscript with contributions and discussion from all of the co-authors. All authors have given approval to the final version of the manuscript.

\section{ACKNOWLEDGMENT}

This work was supported by the Brazilian National Council for Scientific and Technological Development (CNPq) under research grants N. 246725/2012-5.

\section{SUPPLEMENTARY MATERIAL}

The Supplementary Material for this article can be found online at: http://journal.frontiersin.org/article/10.3389/fpls.2016.01236

photosynthesis and sink metabolism in Arabidopsis leaves. Planta 225, 1-12. doi: 10.1007/s00425-006-0303-3

Bordiec, S., Paquis, S., Lacroix, H., Dhondt, S., Ait Barka, E., Kauffmann, S., et al. (2011). Comparative analysis of defence responses induced by the endophytic plant growth-promoting rhizobacterium Burkholderia phytofirmans strain PsJN and the non-host bacterium Pseudomonas syringae pv. pisi in grapevine cell suspensions. J. Exp. Bot. 62, 595-603. doi: 10.1093/jxb/erq291

Boubakri, H., Wahab, M. A., Chong, J., Bertsch, C., Mliki, A., and SoustreGacougnolle, I. (2012). Thiamine induced resistance to Plasmopara viticola in grapevine and elicited host-defense responses, including HR like-cell death. Plant Physiol. Biochem. 57, 120-133. doi: 10.1016/j.plaphy.2012. 05.016

Chen, L. Q., Hou, B. H., Lalonde, S., Takanaga, H., Hartung, M. L., Qu, X. Q., et al. (2010). Sugar transporters for intercellular exchange and nutrition of pathogens. Nature 468, 527-532. doi: 10.1038/nature09606

Chou, H. M., Bundock, N., Rolfe, S. A., and Scholes, J. D. (2000). Infection of Arabidopsis thaliana leaves with Albugo candida (white blister rust) causes a reprogramming of host metabolism. Mol. Plant Pathol. 1, 99-113. doi: 10.1046/j.1364-3703.2000.00013.x

Compant, S., Reiter, B., Sessitsch, A., Nowak, J., Clement, C., and Ait Barka, E. (2005). Endophytic colonization of Vitis vinifera L. by plant growth-promoting bacterium Burkholderia sp. strain PsJN. Appl. Environ. Microbiol. 71, 16851693. doi: 10.1128/AEM.71.4.1685-1693.2005

Conn, K. L., Nowak, J., and Lazarovitz, G. (1997). A gnotobiotic bioassay for studying interactions between potato and plant growth-promoting rhizobacteria. Can. J. Microbiol. 43, 801-808. doi: 10.1139/m97-117 
Dangl, J. L., and Jones, J. D. (2001). Plant pathogens and integrated defence responses to infection. Nature 411, 826-833. doi: 10.1038/35081161

Doehlemann, G., Molitor, F., and Hahn, M. (2005). Molecular and functional characterization of a fructose specific transporter from the gray mold fungus Botrytis cinerea. Fungal Genet. Biol. 42, 601-610. doi: 10.1016/j.fgb.2005.03.001

Ellinger, D., and Voigt, C. A. (2014). Callose biosynthesis in Arabidopsis with a focus on pathogen response: what we have learned within the last decade. Ann. Bot. 114, 1349-1358. doi: 10.1093/aob/mcu120

Fernandez, O., Theocharis, A., Bordiec, S., Feil, R., Jacquens, L., Clement, C., et al. (2012a). Burkholderia phytofirmans PsJN acclimates grapevine to cold by modulating carbohydrate metabolism. Mol. Plant Microbe Interact. 25, 496-504. doi: 10.1094/MPMI-09-11-0245

Fernandez, O., Vandesteene, L., Feil, R., Baillieul, F., Lunn, J. E., and Clement, C. (2012b). Trehalose metabolism is activated upon chilling in grapevine and might participate in Burkholderia phytofirmans induced chilling tolerance. Planta 236, 355-369. doi: 10.1007/s00425-012-1611-4

Ferrari, S., Plotnikova, J. M., De Lorenzo, G., and Ausubel, F. M. (2003). Arabidopsis local resistance to Botrytis cinerea involves salicylic acid and camalexin and requires EDS4 and PAD2, but not SID2, EDS5 or PAD4. Plant J. 35, 193-205. doi: 10.1046/j.1365-313X.2003.01794.x

Gamm, M., Heloir, M. C., Bligny, R., Vaillant-Gaveau, N., Trouvelot, S., Alcaraz, G., et al. (2011). Changes in carbohydrate metabolism in Plasmopara viticolainfected grapevine leaves. Mol. Plant Microbe Interact. 24, 1061-1073. doi: 10.1094/MPMI-02-11-0040

Gauthier, A., Trouvelot, S., Kelloniemi, J., Frettinger, P., Wendehenne, D., Daire, X., et al. (2014). The sulfated laminarin triggers a stress transcriptome before priming the SA- and ROS-dependent defenses during grapevine's induced resistance against Plasmopara viticola. PLoS ONE 9:e88145. doi: 10.1371/journal.pone.0088145

Genty, B., Briantais, J.-M., and Baker, N. R. (1989). The relationship between the quantum yield of photosynthetic electron transport and quenching of chlorophyll fluorescence. Biochim. Biophys. Acta 990, 87-92. doi: 10.1016/S0304-4165(89)80016-9

Glazebrook, J. (2005). Contrasting mechanisms of defense against biotrophic and necrotrophic pathogens. Annu. Rev. Phytopathol. 43, 205-227. doi: 10.1146/annurev.phyto.43.040204.135923

Gruau, C., Trotel-Aziz, P., Villaume, S., Rabenoelina, F., Clement, C., Baillieul, F., et al. (2015). Pseudomonas fluorescens PTA-CT2 triggers local and systemic immune response against Botrytis cinerea in grapevine. Mol. Plant Microbe Interact. 28, 1117-1129. doi: 10.1094/MPMI-04-15-0092-R

Hayes, M. A., Davies, C., and Dry, I. B. (2007). Isolation, functional characterization, and expression analysis of grapevine (Vitis vinifera L.) hexose transporters: differential roles in sink and source tissues. J. Exp. Bot. 58, 1985-1997. doi: 10.1093/jxb/erm061

Hayes, M. A., Feechan, A., and Dry, I. B. (2010). Involvement of abscisic acid in the coordinated regulation of a stress-inducible hexose transporter (VvHT5) and a cell wall invertase in grapevine in response to biotrophic fungal infection. Plant Physiol. 153, 211-221. doi: 10.1104/pp.110.154765

Herbers, K., Meuwly, P., Metraux, J. P., and Sonnewald, U. (1996). Salicylic acidindependent induction of pathogenesis-related protein transcripts by sugars is dependent on leaf developmental stage. FEBS Lett. 397, 239-244. doi: 10.1016/S0014-5793(96)01183-0

Horton, P., and Ruban, A. (2005). Molecular design of the photosystem II light-harvesting antenna: photosynthesis and photoprotection. J. Exp. Bot. 56, 365-373. doi: 10.1093/jxb/eri023

Huang, K., Czymmek, K. J., Caplan, J. L., Sweigard, J. A., and Donofrio, N. M. (2011). HYR1-mediated detoxification of reactive oxygen species is required for full virulence in the rice blast fungus. PLoS Pathog. 7:e1001335. doi: 10.1371/journal.ppat.1001335

Hubalek, V. (2009). Response of Potato (Solanum tuberosum L.) to Lipopolyssacharides Derived from Burkholderia Phytofirmans Strain PsJN. Magistra der Naturwissenschaften (Mag. rer. nat.). Wien: Universität Wien.

Jones, J. D., and Dangl, J. L. (2006). The plant immune system. Nature 444, 323-329. doi: 10.1038/nature05286

Kim, S., Lowman, S., Hou, G., Nowak, J., Flinn, B., and Mei, C. (2012). Growth promotion and colonization of switchgrass (Panicum virgatum) cv. Alamo by bacterial endophyte Burkholderia phytofirmans strain PsJN. Biotechnol. Biofuels 5, 37. doi: 10.1186/1754-6834-5-37
Koch, E., and Slusarenko, A. (1990). Arabidopsis is susceptible to infection by a downy mildew fungus. Plant Cell 2, 437-445.

Kramer, D. M., Avenson, T. J., and Edwards, G. E. (2004). Dynamic flexibility in the light reactions of photosynthesis governed by both electron and proton transfer reactions. Trends Plant Sci. 9, 349-357. doi: 10.1016/j.tplants.2004. 05.001

Lu, X., Tintor, N., Mentzel, T., Kombrink, E., Boller, T., Robatzek, S., et al. (2009). Uncoupling of sustained MAMP receptor signaling from early outputs in an Arabidopsis endoplasmic reticulum glucosidase II allele. Proc. Natl. Acad. Sci. U.S.A. 106, 22522-22527. doi: 10.1073/pnas.0907711106

Luna, E., Pastor, V., Robert, J., Flors, V., Mauch-Mani, B., and Ton, J. (2011). Callose deposition: a multifaceted plant defense response. Mol. Plant Microbe Interact. 24, 183-193. doi: 10.1094/MPMI-07-10-0149

Malinovsky, F. G., Fangel, J. U., and Willats, W. G. T. (2014). The role of the cell wall in plant immunity. Front. Plant Sci. 5:178. doi: 10.3389/fpls.2014.00178

Mur, L. A., Kenton, P., Lloyd, A. J., Ougham, H., and Prats, E. (2008). The hypersensitive response; the centenary is upon us but how much do we know? J. Exp. Bot. 59, 501-520. doi: 10.1093/jxb/erm239

Naveed, M., Baqir Hussain, M., Zahir, Z. A., Mitter, B., and Sessitsch, A. (2014). Drought stress amelioration in wheat through inoculation with Burkholderia phytofirmans strain PsJN. Plant Growth Regul. 73, 121-131.

Nowak, J., Asiedu, S. K., Bensalim, S., Richards, J., Stewart, A., Smith, C., et al. (1998). From laboratory to applications: challenges and progress with in vitro dual cultures of potato and beneficial bacteria. Plant Cell Tissue Organ Cult. 52, 97-103. doi: 10.1023/A:1005965822698

Pastor, V., Luna, E., Ton, J., Cerezo, M., Garcia-Agustin, P., and Flors, V. (2013). Fine tuning of reactive oxygen species homeostasis regulates primed immune responses in Arabidopsis. Mol. Plant Microbe Interact. 26, 1334-1344. doi: 10.1094/MPMI-04-13-0117-R

Pieterse, C. M., Leon-Reyes, A., Van der Ent, S., and Van Wees, S. C. (2009). Networking by small-molecule hormones in plant immunity. Nat. Chem. Biol. 5, 308-316. doi: 10.1038/nchembio.164

Pinedo, I., Ledger, T., Greve, M., and Poupin, M. J. (2015). Burkholderia phytofirmans PsIN induces long-term metabolic and transcriptional changes involved in Arabidopsis thaliana salt tolerance. Front. Plant Sci. 6:466. doi: $10.3389 /$ fpls.2015.00466

Roitsch, T., Balibrea, M. E., Hofmann, M., Proels, R., and Sinha, A. K. (2003). Extracellular invertase: key metabolic enzyme and PR protein. J. Exp. Bot. 54, 513-524. doi: 10.1093/jxb/erg050

Roitsch, T., and Gonzalez, M. C. (2004). Function and regulation of plant invertases: sweet sensations. Trends Plant Sci. 9, 606-613. doi: 10.1016/j.tplants.2004.10.009

Rojas, C., Senthil-Kumar, M., Tzin, V., and Mysore, M. (2014). Regulation of primary plant metabolism during plant-pathogen interactions and its contribution to plant defense. Front. Plant Sci. 5:17. doi: 10.3389/fpls.2014.00017

Sanchez, L., Courteaux, B., Hubert, J., Kauffmann, S., Renault, J. H., Clement, C., et al. (2012). Rhamnolipids elicit defense responses and induce disease resistance against biotrophic, hemibiotrophic, and necrotrophic pathogens that require different signaling pathways in Arabidopsis and highlight a central role for salicylic acid. Plant Physiol. 160, 1630-1641. doi: 10.1104/pp.112. 201913

Schenk, S. T., Hernandez-Reyes, C., Samans, B., Stein, E., Neumann, C., Schikora, M., et al. (2014). N-acyl-homoserine lactone primes plants for cell wall reinforcement and induces resistance to bacterial pathogens via the salicylic acid/oxylipin pathway. Plant Cell 26, 2708-2723. doi: 10.1105/tpc.114. 126763

Sessitsch, A., Coenye, T., Sturz, A. V., Vandamme, P., Barka, E. A., Salles, J. F., et al. (2005). Burkholderia phytofirmans sp. nov., a novel plant-associated bacterium with plant-beneficial properties. Int. J. Syst. Evol. Microbiol. 55(Pt 3), 1187-1192. doi: 10.1099/ijs.0.63149-0

Sharma, V. K., and Nowak, J. (1998). Enhancement of Verticillium wilt resistance in tomato transplants by in vitro co-culture of seedlings with a plant growthpromoting rhizobacterium (Pseudomonas sp. strain PsJN). Can. J. Microbiol. 44, 528-536. doi: 10.1139/w98-017

Shoresh, M., Harman, G. E., and Mastouri, F. (2010). Induced systemic resistance and plant responses to fungal biocontrol agents. Annu. Rev. Phytopathol. 48, 21-43. doi: 10.1146/annurev-phyto-073009-114450 
Solfanelli, C., Poggi, A., Loreti, E., Alpi, A., and Perata, P. (2006). Sucrosespecific induction of the anthocyanin biosynthetic pathway in Arabidopsis. Plant Physiol. 140, 637-646. doi: 10.1104/pp.105.072579

Su, F., Jacquard, C., Villaume, S., Michel, J., Rabenoelina, F., Clement, C., et al. (2015). Burkholderia phytofirmans PsJN reduces impact of freezing temperatures on photosynthesis in Arabidopsis thaliana. Front. Plant Sci. 6:810. doi: $10.3389 /$ fpls.2015.00810

Sun, A., Nie, S., and Xing, D. (2012). Nitric oxide-mediated maintenance of redox homeostasis contributes to NPR1-dependent plant innate immunity triggered by lipopolysaccharides. Plant Physiol. 160, 1081-1096. doi: 10.1104/pp.112.201798

Tauzin, A. S., and Giardina, T. (2014). Sucrose and invertases, a part of the plant defense response to the biotic stresses. Front. Plant Sci. 5:293. doi: 10.3389/fpls.2014.00293

Theocharis, A., Bordiec, S., Fernandez, O., Paquis, S., Dhondt-Cordelier, S., Baillieul, F., et al. (2012). Burkholderia phytofirmans PsJN primes Vitis vinifera L. and confers a better tolerance to low nonfreezing temperatures. Mol. Plant Microbe Interact. 25, 241-249. doi: 10.1094/MPMI-05-11-0124

Thordal-Christensen, H., Zhang, Z., Wei, Y., and Collinge, D. B. (1997). Subcellular localization of $\mathrm{H} 2 \mathrm{O} 2$ in plants. $\mathrm{H} 2 \mathrm{O} 2$ accumulation in papillae and hypersensitive response during the barley-powdery mildew interaction. Plant J. 11, 1187-1194.

Torres, M. A., Jones, J. D., and Dangl, J. L. (2006). Reactive oxygen species signaling in response to pathogens. Plant Physiol. 141, 373-378. doi: 10.1104/pp.106.079467

Trda, L., Fernandez, O., Boutrot, F., Heloir, M. C., Kelloniemi, J., Daire, X., et al. (2014). The grapevine flagellin receptor VvFLS2 differentially recognizes flagellin-derived epitopes from the endophytic growth-promoting bacterium Burkholderia phytofirmans and plant pathogenic bacteria. New Phytol. 201, 1371-1384. doi: 10.1111/nph.12592

Trouvelot, S., Heloir, M. C., Poinssot, B., Gauthier, A., Paris, F., Guillier, C., et al. (2014). Carbohydrates in plant immunity and plant protection: roles and potential application as foliar sprays. Front. Plant Sci. 5:592. doi: 10.3389/fpls.2014.00592

Trouvelot, S., Varnier, A. L., Allegre, M., Mercier, L., Baillieul, F., Arnould, C., et al. (2008). A beta-1,3 glucan sulfate induces resistance in grapevine against Plasmopara viticola through priming of defense responses, including HR-like cell death. Mol. Plant Microbe Interact. 21, 232-243. doi: 10.1094/MPMI-21-20232

Tsuda, K., and Katagiri, F. (2010). Comparing signaling mechanisms engaged in pattern-triggered and effector-triggered immunity. Curr. Opin. Plant Biol. 13, 459-465. doi: 10.1016/j.pbi.2010.04.006

Underwood, W. (2012). The plant cell wall: a dynamic barrier against pathogen invasion. Front. Plant Sci. 3:85. doi: 10.3389/fpls.2012. 00085

Verhagen, B., Trotel-Aziz, P., Jeandet, P., Baillieul, F., and Aziz, A. (2011). Improved resistance against Botrytis cinerea by grapevine-associated bacteria that induce a prime oxidative burst and phytoalexin production. Phytopathology 101, 768-777. doi: 10.1094/PHYTO-09-10-0242

Verhagen, B. W., Trotel-Aziz, P., Couderchet, M., Hofte, M., and Aziz, A. (2010). Pseudomonas spp.-induced systemic resistance to Botrytis cinerea is associated with induction and priming of defence responses in grapevine. J. Exp. Bot. 61, 249-260. doi: 10.1093/jxb/erp295

Vignault, C., Vachaud, M., Cakir, B., Glissant, D., Dedaldechamp, F., Buttner, M., et al. (2005). VvHT1 encodes a monosaccharide transporter expressed in the conducting complex of the grape berry phloem. J. Exp. Bot. 56, 1409-1418. doi: $10.1093 / \mathrm{jxb} / \mathrm{eri} 142$

Yang, J., Kloepper, J. W., and Ryu, C. M. (2009). Rhizosphere bacteria help plants tolerate abiotic stress. Trends Plant Sci. 14, 1-4. doi: 10.1016/j.tplants.2008.10.004

Zipfel, C. (2008). Pattern-recognition receptors in plant innate immunity. Curr. Opin. Immunol. 20, 10-16. doi: 10.1016/j.coi.2007.11.003

Conflict of Interest Statement: The authors declare that the research was conducted in the absence of any commercial or financial relationships that could be construed as a potential conflict of interest.

Copyright (c) 2016 Miotto-Vilanova, Jacquard, Courteaux, Wortham, Michel, Clément, Barka and Sanchez. This is an open-access article distributed under the terms of the Creative Commons Attribution License (CC BY). The use, distribution or reproduction in other forums is permitted, provided the original author(s) or licensor are credited and that the original publication in this journal is cited, in accordance with accepted academic practice. No use, distribution or reproduction is permitted which does not comply with these terms. 